\title{
Paleoceanography and ice sheet variability offshore Wilkes Land, Antarctica - Part 1: Insights from late Oligocene astronomically paced contourite sedimentation
}

\author{
Ariadna Salabarnada ${ }^{1, *}$, Carlota Escutia ${ }^{1}$, Ursula Röhl ${ }^{2}$, C. Hans Nelson ${ }^{1}$, Robert McKay ${ }^{3}$, \\ Francisco J. Jiménez-Espejo ${ }^{4}$, Peter K. Bijl ${ }^{5}$, Julian D. Hartman ${ }^{5}$, Stephanie L. Strother ${ }^{6}$, Ulrich Salzmann ${ }^{6}$, \\ Dimitris Evangelinos ${ }^{1}$, Adrián López-Quirós ${ }^{1}$, José Abel Flores ${ }^{7}$, Francesca Sangiorgi ${ }^{5}$, Minoru Ikehara ${ }^{8}$, and \\ Henk Brinkhuis ${ }^{5,9}$ \\ ${ }^{1}$ Instituto Andaluz de Ciencias de la Tierra, CSIC-Univ. de Granada, Armilla, 18100, Spain \\ ${ }^{2}$ MARUM - Center for Marine Environmental Sciences, University of Bremen, Leobener Strasse 8, 28359 Bremen, Germany \\ ${ }^{3}$ Antarctic Research Centre, Victoria University of Wellington, Wellington, 6140, New Zealand \\ ${ }^{4}$ Department of Biogeochemistry, Japan Agency for Marine-Earth Science and Technology, \\ Yokosuka, Kanagawa, 237-0061, Japan \\ ${ }^{5}$ Department of Earth Sciences, Marine Palynology and Palaeoceanography, Faculty of Geosciences, Laboratory of \\ Palaeobotany and Palynology, Utrecht University, Princetonlaan 8a, 3584 CB Utrecht, the Netherlands \\ ${ }^{6}$ Department of Geography and Environmental Sciences, Faculty of Engineering and Environment, \\ Northumbria University, Newcastle upon Tyne, NE1 8ST, UK \\ ${ }^{7}$ Department of Geology, University of Salamanca, Salamanca, 37008, Spain \\ ${ }^{8}$ Center for Advanced Marine Core research, Kochi University, Nankoku, Kochi, 783-8502, Japan \\ ${ }^{9}$ NIOZ, Royal Netherlands Institute for Sea Research, and Utrecht University, Landsdiep 4, \\ 1797SZ 't Horntje, Texel, the Netherlands \\ *Invited contribution by Ariadna Salabarnada, recipient of the EGU Climate: Past, Present \& \\ Future Outstanding Student Poster and PICO Award 2016.
}

Correspondence: Ariadna Salabarnada (a.salabarnada@csic.es)

Received: 16 November 2017 - Discussion started: 5 December 2017

Revised: 2 May 2018 - Accepted: 21 June 2018 - Published: 10 July 2018

\begin{abstract}
Antarctic ice sheet and Southern Ocean paleoceanographic configurations during the late Oligocene are not well resolved. They are however important to understand the influence of high-latitude Southern Hemisphere feedbacks on global climate under $\mathrm{CO}_{2}$ scenarios (between 400 and $750 \mathrm{ppm}$ ) projected by the IPCC for this century, assuming unabated $\mathrm{CO}_{2}$ emissions. Sediments recovered by the Integrated Ocean Drilling Program (IODP) at Site U1356, offshore of the Wilkes Land margin in East Antarctica, provide an opportunity to study ice sheet and paleoceanographic configurations during the late Oligocene (26-25 Ma). Our study, based on a combination of sediment facies analysis, magnetic susceptibility, density, and X-ray fluorescence geochemical data, shows that glacial and interglacial sediments are continuously reworked by bottom currents, with maximum veloc-
\end{abstract}

ities occurring during the interglacial periods. Glacial sediments record poorly ventilated, low-oxygenation bottom water conditions, interpreted as resulting from a northward shift of westerly winds and surface oceanic fronts. Interglacial sediments record more oxygenated and ventilated bottom water conditions and strong current velocities, which suggests enhanced mixing of the water masses as a result of a southward shift of the polar front. Intervals with preserved carbonated nannofossils within some of the interglacial facies are interpreted as forming under warmer paleoclimatic conditions when less corrosive warmer northern component water (e.g., North Atlantic sourced deep water) had a greater influence on the site. Spectral analysis on the late Oligocene sediment interval shows that the glacial-interglacial cyclicity and related displacements of the Southern Ocean frontal 
systems between 26 and 25 Ma were forced mainly by obliquity. The paucity of iceberg-rafted debris (IRD) throughout the studied interval contrasts with earlier Oligocene and postMiocene Climate Optimum sections from Site U1356 and with late Oligocene strata from the Ross Sea, which contain IRD and evidence for coastal glaciers and sea ice. These observations, supported by elevated sea surface paleotemperatures, the absence of sea ice, and reconstructions of fossil pollen between 26 and $25 \mathrm{Ma}$ at Site U1356, suggest that open-ocean water conditions prevailed. Combined, this evidence suggests that glaciers or ice caps likely occupied the topographic highs and lowlands of the now marine Wilkes Subglacial Basin (WSB). Unlike today, the continental shelf was not overdeepened and thus ice sheets in the WSB were likely land-based, and marine-based ice sheet expansion was likely limited to coastal regions.

\section{Introduction}

Today, ice sheets on Antarctica contain about 26.5 million $\mathrm{km}^{3}$ of ice, which has the potential for raising global average sea level by $58 \mathrm{~m}$, with the East Antarctic Ice Sheet constituting $53.3 \mathrm{~m}$ of this sea level equivalent (Fretwell et al., 2013). Satellite observations indicate significant rates of change in most of the West Antarctic Ice Sheet (WAIS) and some sectors of the East Antarctic Ice Sheet (EAIS). These include thinning at their seaward margins (Pritchard et al., 2012) and accelerating ice shelves' basal melt rates (Rignot et al., 2013; Shen et al., 2018). Given the uncertainties in projections of future ice sheet melt, there has been a growing number of studies of sedimentary sections from the surrounding margins of Antarctica targeting records of past warm intervals (i.e., high- $\mathrm{CO}_{2}$ and elevated temperature climates) in order to better understand ice sheets and Southern Ocean configurations under these conditions. For example, the early Pliocene (5-3 Ma) has been targeted because atmospheric $\mathrm{CO}_{2}$ concentrations were similar to today's $400 \mathrm{ppmv}$ concentrations (Foster and Rohling, 2013; Zhang et al., 2013). These studies have shown that early Pliocene Southern Ocean surface waters were warmer (i.e., between $2.5->4^{\circ} \mathrm{C}$ ) than present and that the summer sea ice cover was greatly reduced or even absent (Bohaty and Hardwood, 1998; Whitehead and Bohaty, 2003; Escutia et al., 2009; Cook et al., 2013). They also record the periodic collapse of both the WAIS and EAIS marine-based margins (Naish et al., 2009; Pollard and DeConto, 2009; Cook et al., 2013; Reinardy et al., 2015; DeConto and Pollard, 2016). Foster and Rohling (2013) provide a sigmoidal relationship between eustatic sea level and atmospheric $\mathrm{CO}_{2}$ levels whereby sea levels stabilize at $\sim 22 \pm 12 \mathrm{~m}$ above the present-day level between about 400 and $650 \mathrm{ppm}$, suggesting loss of the Greenland Ice Sheet $(6-7 \mathrm{~m}$ s.l.e.) and the marine-based West Antarctic Ice Sheet $(+7 \mathrm{~m}$ s.l.e.). This implies that continental EAIS volumes remained relatively stable during these times but experienced mass loss of some (or all) of its marine-based margins, relative to the present day. With $\mathrm{CO}_{2}$ concentrations at $>650 \mathrm{ppm}$, they infer further increases in sea level, suggesting this as a threshold for initiating the retreat of the terrestrial margins of EAIS. With sustained warming, $\mathrm{CO}_{2}$ concentrations of more than $650 \mathrm{ppmv}$ are within the projections for this century (Solomon, 2007; Field et al., 2014). The last time the atmosphere is thought to have experienced $\mathrm{CO}_{2}$ concentrations above $650 \mathrm{ppmv}$ was during the Oligocene (23.03-33.9 Ma), when $\mathrm{CO}_{2}$ values remained between 400 and $\sim 750-800 \mathrm{ppm}$ (Pagani et al., 2005; Beerling and Royer, 2011; Zhang et al., 2013).

Geological records of heavy isotope values $\sim 2.5 \%$ and far-field sea level records from passive margins during the Oligocene suggest that, following the continental-wide expansion of ice during the Eocene-Oligocene Transition that culminated at the Oi-1 event (33.6 Ma), the Antarctic ice cover was at least $\sim 50 \%$ of the current volume (e.g., Kominz and Pekar, 2001; Zachos et al., 2001; Coxall et al., 2005; Pekar et al., 2006; Liebrand et al., 2011, 2017; Mudelsee et al., 2014). The early part of the Oligocene records a significant $\delta^{18} \mathrm{O}$ decreasing slope with high-latitude sites exhibiting a strong deglaciation/warming that persisted until $\sim 32 \mathrm{Ma}$ (Mudelsee et al., 2014). This was followed by seemingly stable conditions on Antarctica as evidenced by minimal $\delta^{18} \mathrm{O}$ and $\mathrm{Mg} / \mathrm{Ca}$ changes (Billups and Schrag, 2003; Lear et al., 2004; Mudelsee et al., 2014). A slight glaciation/cooling is recorded before 28 to $\sim 27 \mathrm{Ma}$, which was followed by an up to $1 \%$ long-term decrease in the $\delta^{18} \mathrm{O}$ isotope records that was interpreted as resulting from the deglaciation of large parts of the Antarctic ice sheets during a significant warming trend in the late Oligocene (27-26 Ma) (Zachos et al., 2001). Nevertheless, there are marked differences between the late Oligocene low $\delta^{18} \mathrm{O}$ values recorded at Pacific, Indian, and Atlantic Ocean sites (e.g., Pälike et al., 2006; Cramer et al., 2009; Liebrand et al., 2011; Mudelsee et al., 2014; Hauptvogel et al., 2017) and the sustained high $\delta^{18} \mathrm{O}$ values recorded at Southern Ocean sites (Pekar et al., 2006; Mudelsee et al., 2014). High $\delta^{18} \mathrm{O}$ values in the Southern Ocean sediments are in agreement with the ice proximal record recovered by the Cape Roberts Project (CRP) in the Ross Sea, which shows the existence of glaciers/ice sheets at sea level (Barrett et al., 2007; Hauptvogel et al., 2017). Based on the study of the isotopic record in sediments from the Atlantic, the Indian, and the equatorial Pacific, Pekar et al. (2006) explained this conundrum of a glaciated Antarctica and varying intra-basinal $\delta^{18} \mathrm{O}$ values with the coeval existence of two deep-water masses, one sourced from Antarctica and another, warmer bottom water, sourced from lower latitudes. Superimposed on the above long-term swings in the $\delta^{18} \mathrm{O}$ Oligocene record, fluctuations on timescales shorter than several million years were identified in the high-resolution benthic $\delta^{13} \mathrm{C}$ record from ODP 1218 (Pälike et al., 2006). These fluctuations in periods of $405 \mathrm{kyr}$ and $1.2 \mathrm{Myr}$ are re- 
lated to Earth's orbital variations in eccentricity and obliquity, respectively, and have been referred to as the short-term "heartbeat" of the Oligocene climate (Pälike et al., 2006). Oligocene records close to Antarctica are needed to better resolve Antarctic ice sheet and paleoceanographic configurations at different timescales and under scenarios of increasing atmospheric $\mathrm{CO}_{2}$ concentrations.

Integrated Ocean Drilling Program (IODP) Expedition 318 drilled a transect of sites across the eastern Wilkes Land margin at the seaward termination of the Wilkes Subglacial Basin (WSB) (Escutia et al., 2011, 2014) (Fig. 1). Relatively good recovery (78.2\%) of late Oligocene (26-25 Ma) sediments from Site U1356 between 689.4 and $641.4 \mathrm{~m}$ below the sea floor ( $\mathrm{m}$ b.s.f.) provides an opportunity to study ice sheet and ocean configurations during the late Oligocene and to relate them to other Antarctic and global records. In this paper, we present a new glacial-interglacial sedimentation and paleoceanographic model for the distal glaciomarine record of the Wilkes Land margin constructed on the basis of sedimentological data (visual core description, facies analysis, computed tomography images, and high-resolution scanning electron microscopy images), physical properties (i.e., magnetic susceptibility of the bulk sediment and grain density), and X-ray fluorescence data (XRF). We also provide insights into the configuration of the ice sheet in this sector of the east Antarctic margin and evidence for orbital forcing of the glaciomarine glacial-interglacial sedimentation at Site U1356.

Together with the companion papers that study the dinoflagellate cyst assemblages (Bijl et al., 2018b), and TEX86-based sea surface temperature reconstructions (Hartman et al., 2018), we explore the role of oceanic forcing and ice sheet configuration during astronomically paced glacial and interglacial periods of the Oligocene and Miocene in the Wilkes Land Margin.

\section{Materials and methods}

\subsection{Site U1356 description}

Site U1356 $\left(63^{\circ} 18.6138^{\prime} \mathrm{S}, 135^{\circ} 59.9376^{\prime} \mathrm{E}\right)$ is located at $3992 \mathrm{~m}$ water depth in front of the glaciated margin of the eastern Wilkes Land Coast of East Antarctica and penetrated $1006 \mathrm{~m}$ into the flank of a levee deposit in the transition between the lower continental rise and the abyssal plain (Escutia et al., 2011; Fig. 1). Overall recovery was $35 \%$ with sediments dated to between the early Eocene and Pliocene, but several intervals provide good stratigraphic control (Escutia et al., 2011; Tauxe et al., 2012). The Oligocene section was recovered between 895 and $430.8 \mathrm{~m}$ b.s.f. (cores U1356-95R-3 $83 \mathrm{~cm}$ to U1356-46R). Our study focuses on the relatively high-recovery $(78.2 \%)$ interval within the late Oligocene, which spans 689.4 to 641.4 m b.s.f. (cores U1356$72 \mathrm{R}$ to $-68 \mathrm{R})$. The sediments from this interval are part of shipboard lithostratigraphic Unit V, which is characterized by light greenish-grey, strongly bioturbated claystones and micritic limestones interbedded with dark brown, sparsely bioturbated, parallel- and ripple-laminated claystones with minor cross-laminated interbeds (Escutia et al., 2011). The bioturbated and calcareous claystones and limestones were broadly interpreted as representing pelagic sedimentation superimposed on the background hemipelagic sedimentary input (Escutia et al., 2011). The laminated claystones and ripple cross-laminated sandstones were interpreted as likely resulting from variations in bottom current strength and finegrained terrigenous supply (Escutia et al., 2011). In addition, a notable absence of iceberg-rafted debris (IRD) $(>250 \mu \mathrm{m})$ in this interval relative to underlying and overlying strata was also recorded.

The late Oligocene depositional setting of Site U1356 was, however, different to that of today. The stratigraphic evolution of the region testifies to the progradation of the continental shelf taking place after continental ice sheet buildup during the Eocene-Oligocene Transition (EOT; 33.6 Ma; Eittreim et al., 1995; Escutia et al., 2005, 2014), which resulted in (1) seismic and sedimentary facies on the continental rise becoming more proximal up-section (Hayes and Frakes, 1975; Escutia et al., 2000, 2005, 2014) and (2) high sedimentation rates during the Oligocene (Escutia et al., 2011; Tauxe et al., 2012). In this context, the studied late Oligocene sediments from Site U1356 record distal continental rise deposition in an incipient/low-relief levee of a submarine channel. As progradation continued, a complex network of welldeveloped channels and high-relief levee systems developed on the continental rise (Escutia et al., 2000) from the latest Oligocene onwards.

Today, Site U1356 lies close to the southern boundary of the Antarctic Circumpolar Current, near the Antarctic Divergence at $\sim 63^{\circ} \mathrm{S}$ (Orsi et al., 1995; Bindoff et al., 2000) (Fig. 1). However, the paleo-latitude of Site U1356 was around $58.5 \pm 2.5^{\circ} \mathrm{S}$ (van Hinsbergen et al., 2015) during the late Oligocene, i.e., more northerly than today. Scher and Martin (2008) and Scher et al. (2015) reconstructed the position of the early Oligocene Antarctic Divergence to be located around $60^{\circ} \mathrm{S}$ (Fig. 1), based on the distribution of terrigenous and biogenic (calcareous and siliceous microfossils) sedimentation, $\mathrm{Nd}$ isotopes, and $\mathrm{Al} / \mathrm{Ti}$ ratios through a core transect across the Australian-Antarctic basin in the Southern Ocean. According to these interpretations, Site U1356 lay far to the north of the Antarctic Divergence zone and was closer to the polar front during the Oligocene.

\subsection{Age model}

The age model for Site U1356 was established on the basis of the magnetostratigraphic datums constrained by marine diatom, radiolaria, calcareous nannoplankton, and dinocyst biostratigraphic control (Escutia et al., 2011; Tauxe et al., 2012; Bijl et al., 2018a). The late Oligocene interval contains three magnetostratigraphic datums (Table 1): (1) Chron 


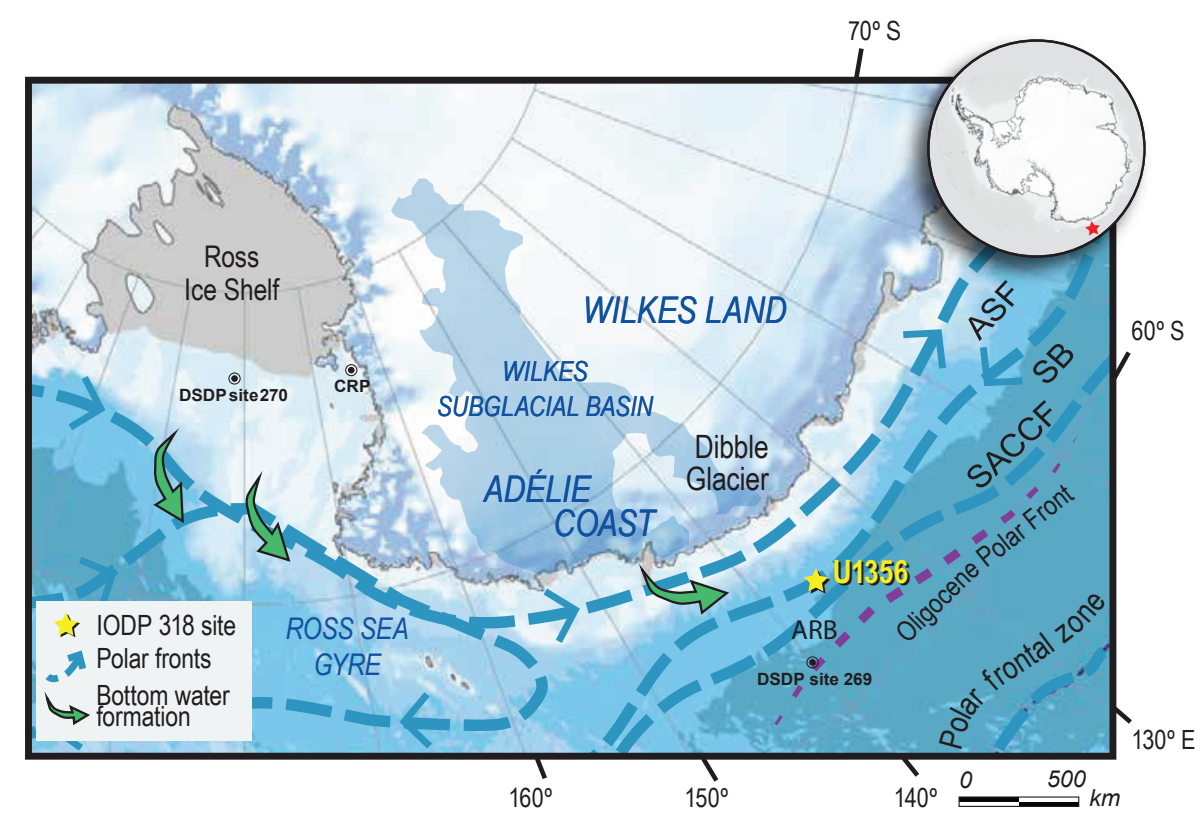

Figure 1. Location of IODP 318 Site U1356 (Escutia et al., 2010) on the Adélie Coast continental rise. Bed topography from IBSCO2 (Arndt et al., 2013). Schematic position of the different water masses at present and locations of Antarctic Bottom Water formation (Orsi, 1995) are indicated. The position of the Oligocene Polar Front (Scher et al., 2015) is also shown. ASF: Antarctic Slope Front; SB: southern boundary; SACCF: Southern Antarctic Counter Current Front; ARB: Adélie Rift Block.

C8n.1n $(o)$ between 643.70 and $643.65 \mathrm{~m}$ b.s.f. (U135668R-2), (2) C8n.2n (y) between 652.60 and $652.55 \mathrm{~m}$ b.s.f. (U1356-69R-2), and (3) C8n.2n (o) between 679.90 and $678.06 \mathrm{~m}$ b.s.f. (U1356-71R). For this study, the age model by Tauxe et al. (2012), which was calibrated to the GTS2004 Time Scale (Gradstein et at., 2004), has been updated using the GTS 2012 Astronomic Age Model (Vandenberghe et al., 2012). Based on this calibration, the age of sediments between 678.98 and $643.37 \mathrm{~m}$ b.s.f. is 25.99 and $25.26 \mathrm{Ma}$, respectively (Fig. 2; Table 1).

\subsection{Facies analyses}

Detailed facies analyses provide a stratigraphic framework on which we base our sedimentary processes and paleoenvironmental interpretations. Lithofacies are determined on the basis of detailed visual logging of the core during a visit to the IODP Gulf Coast Repository (GCR), expanding on the lower-resolution preliminary descriptions in Escutia et al. (2011). We logged the lithology, sedimentary texture (i.e., shape, size, and distribution of particles), and structures with a focus on the contacts between the beds and on bioturbation at a millimeter- to centimeter-scale resolution in cores expanding from 896 to $95.4 \mathrm{mb}$ b.f. (cores U1356-95R to -11R) (see Figs. S1 and S2 in the Supplement). Physical property data were measured during IODP Exp. 318 using the Whole Round Multisensor Logger. Magnetic susceptibility measurements were taken at $2.5 \mathrm{~cm}$ intervals, and natural gamma radiation (NGR) was measured every $10 \mathrm{~cm}$ (Escutia et al., 2011). In this paper, we focus on the interval between 689.4 and $641.4 \mathrm{~m}$ b.s.f., which comprises cores $72 \mathrm{R}$ to $68 \mathrm{R}$ (Fig. 2).

$\mathrm{X}$-ray computed tomography scans (CT scans) measure changes in density and allow for the analysis of finescale stratigraphic changes and internal structures of sedimentary deposits in a nondestructive manner (e.g., Duliu, 1999; St-Onge and Long, 2009; Van Daele et al., 2014; Fouinat et al., 2017). To further characterize the different facies in our cores, selected intervals of Core U135671R-6 (678.11 to 676.91 mb.s.f.) and Core U1356-71R-2 (672.8 to $671.35 \mathrm{~m}$ b.s.f.) were CT-scanned at the Kochi Core Center (KCC) (Japan), with the GE Medical systems LightSpeed Ultra 16. 2-D scout (shooting conditions at $120 \mathrm{Kv}$ with $100 \mathrm{~mA}$; 3-D helical image with $120 \mathrm{Kv}$ and $100 \mathrm{~mA}$ and FOV $=22.0$ ). Image spatial resolution consists of $0.42 \mathrm{~mm} \mathrm{pixel}^{-1}$ with $0.625 \mathrm{~mm}$ of slice thickness (voxel spatial resolution of $0.42 \times 0.42 \times 0.625 \mathrm{~mm}$ ).

The type and composition of biogenic and terrigenous particles, particle size, and morphology of each lithofacies was characterized with a high-resolution scanning electron microscope (HR-SEM) at the Centro de Instrumentación Científica (University of Granada, Spain).

\subsection{X-ray fluorescence analyses}

Detailed bulk-chemical composition records acquired by XRF core scanning allow the accurate determination of sedimentological changes and the assessment of the contribu- 
Table 1. Age model by Tauxe et al. (2012) and transformed ages to GPTS 2012.

\begin{tabular}{ccccccc}
\hline $\begin{array}{c}\text { Core section } \\
\begin{array}{c}\text { Site U1356 } \\
\text { Exp. 318 }\end{array}\end{array}$ & $\begin{array}{c}\text { Top depth } \\
\text { (m b.s.f.) }\end{array}$ & $\begin{array}{c}\text { Bottom depth } \\
\text { (m b.s.f.) }\end{array}$ & $\begin{array}{c}\text { Depth used } \\
(\mathrm{m})\end{array}$ & $\begin{array}{c}\text { GPTS 2004 } \\
\text { (Myr) } \\
\text { (Tauxe } \\
\text { et al., 2012) }\end{array}$ & $\begin{array}{c}\text { GPTS 2012 } \\
\text { (Myr) }\end{array}$ & Chron \\
\hline 68R-2 & 643.10 & 643.65 & 643.37 & 25.444 & 25.260 & C8n.1n $(o)$ \\
69R-2 & 652.55 & 652.60 & 652.57 & 25.492 & 25.300 & C8n.2n $(y)$ \\
71R-6 & 678.06 & 679.90 & 678.98 & 26.154 & 25.990 & C8n.2n $(o)$ \\
\hline
\end{tabular}

tion of the various components in the biogenic and lithogenic fraction in marine sediments (Croudace et al., 2006). This nondestructive method yields element intensities on the surface of split sediment cores and provides statistically significant data for major and minor elements (Richter et al., 2006; O'Regan et al., 2010; Wilhelms-Dick et al., 2012). The data are given as element intensities in total counts.

XRF core scanning measurements were collected every $2 \mathrm{~cm}$ down-core over a $1 \mathrm{~cm}^{2}$ area with a split size of $10 \mathrm{~mm}$, a current of $0.2 \mathrm{~mA}$ (Al-Fe) and $1.5 \mathrm{~mA}$ (all other elements), and a sampling time of $20 \mathrm{~s}$, directly at the split core surface of the archive half with XRF Core Scanner III at the MARUM - Center for Marine Environmental Sciences, University of Bremen, Germany. Prior to the scanning, cores were thermally equilibrated to room temperature; the surface was cleaned, flattened, and covered with $4 \mu \mathrm{m}$ thin SPEXCerti Prep Ultralene1 foil to protect the sensor and prevent contamination during the scanning procedure. Scans were collected during three separate runs using generator settings of $10 \mathrm{kV}$ for the elements $\mathrm{Al}, \mathrm{Si}, \mathrm{S}, \mathrm{K}, \mathrm{Ca}, \mathrm{Ti}, \mathrm{Mn}, \mathrm{Fe} ; 30 \mathrm{kV}$ for elements such as $\mathrm{Br}, \mathrm{Rb}, \mathrm{Zr}, \mathrm{Mo}, \mathrm{Pb}$; and $50 \mathrm{kV}$ for $\mathrm{Ba}$. The data reported here were acquired by a Canberra X-PIPS silicon drift detector (SDD; Model SXD 15C-150-500) with $150 \mathrm{eV}$ X-ray resolution, the Canberra Digital Spectrum Analyzer DAS 1000, and an Oxford Instruments $100 \mathrm{~W}$ Neptune X-ray tube with rhodium (Rh) target material. Raw data spectra were processed by the "Analysis of X-ray spectra by Iterative Least square software" (WIN AXIL) package from Canberra Eurisys. Data points from disturbed intervals in the core face (i.e., slight fractures and cracks) were removed.

The light elements Al, Si, and K show large element variations (intra-element variations of 1 order of magnitude or more; Fig. 2). Similar variations have been previously described in sediment cores to indicate substantial analytical deviations due to physical sedimentary properties (i.e., Tjallingii and Röhl et al., 2007; Hennekam and de Lange, 2012). Accordingly, for this study we have discarded the continuous records of $\mathrm{Al}, \mathrm{Si}$, and $\mathrm{K}$ and concentrated our interpretations on $\mathrm{Al}, \mathrm{Si}$, and $\mathrm{K}$ values from the XRF analyses in discrete samples (see below). As Titanium (Ti) is restricted to the terrigenous phase in sediments and is inert to diagenetic processes (Calvert and Pedersen, 2007), we utilized Ti to normalize other chemical elements for the terrigenous fraction.
Linear correlation (r Pearson) above standardized values has been done in order to find statistical relationships among the variables.

In addition, we conducted measurements of a total of 50 major and minor trace elements in 25 discrete sediment samples collected at 0.4 and $1 \mathrm{~m}$ spacing to determine their chemical composition. For this, we used a Pioneer-Bruker XRF spectrometer S4 at the Instituto Andaluz de Ciencias de la Tierra (CSIC-UGR) in Spain, equipped with a Rh tube $(60 \mathrm{kV}, 150 \mathrm{~mA})$ using internal standards. The samples were prepared in a Vulcan 4Mfusion machine and the analyses performed using a standard-less spectrum sweep with the Spectraplus software.

\subsection{Spectral analyses}

We selected key environmental indicators from XRF core scanner data and elemental ratios (i.e., $\mathrm{Zr} / \mathrm{Ba}, \mathrm{Ba}, \mathrm{Zr} / \mathrm{Ti}$, $\mathrm{Ca} / \mathrm{Ti}$, magnetic susceptibility (MS)) to conduct spectral analyses on the data from the interval between 689.4 to $641.4 \mathrm{~m}$ b.s.f. (cores U1356-72R to 68R). We performed an evolutionary spectral and harmonic analysis on each dataset using the Astrochron toolkit in the R software (Meyers, 2014). A detailed methodology is provided in the Supplement, following the Astrochron code of Wanlu et al. (2016). This method allows the detection of nonstationary spectra variability within the time series. The time series were analyzed on the depth scale and then, applying the Frequency domain minimal tuning (Meyers et al., 2001), we converted spatial frequencies to sedimentation rates using an average period of $41 \mathrm{kyr}$ to transform them to an age scale, on the basis of the already resolved age model. The evolutionary average spectral misfit method was then used to resolve unevenly sampled series and changing sedimentation rates (Meyers et al., 2012). This method is used to test a range of plausible timescales and simultaneously evaluate the reliability of the presence of astronomical cycles (Sect. S2).

\section{Results}

\subsection{Sedimentary facies}

The revised Oligocene facies log (Figs. S1, S2) includes the high-recovery interval between 689.4 and $641.4 \mathrm{~m}$ b.s.f. 


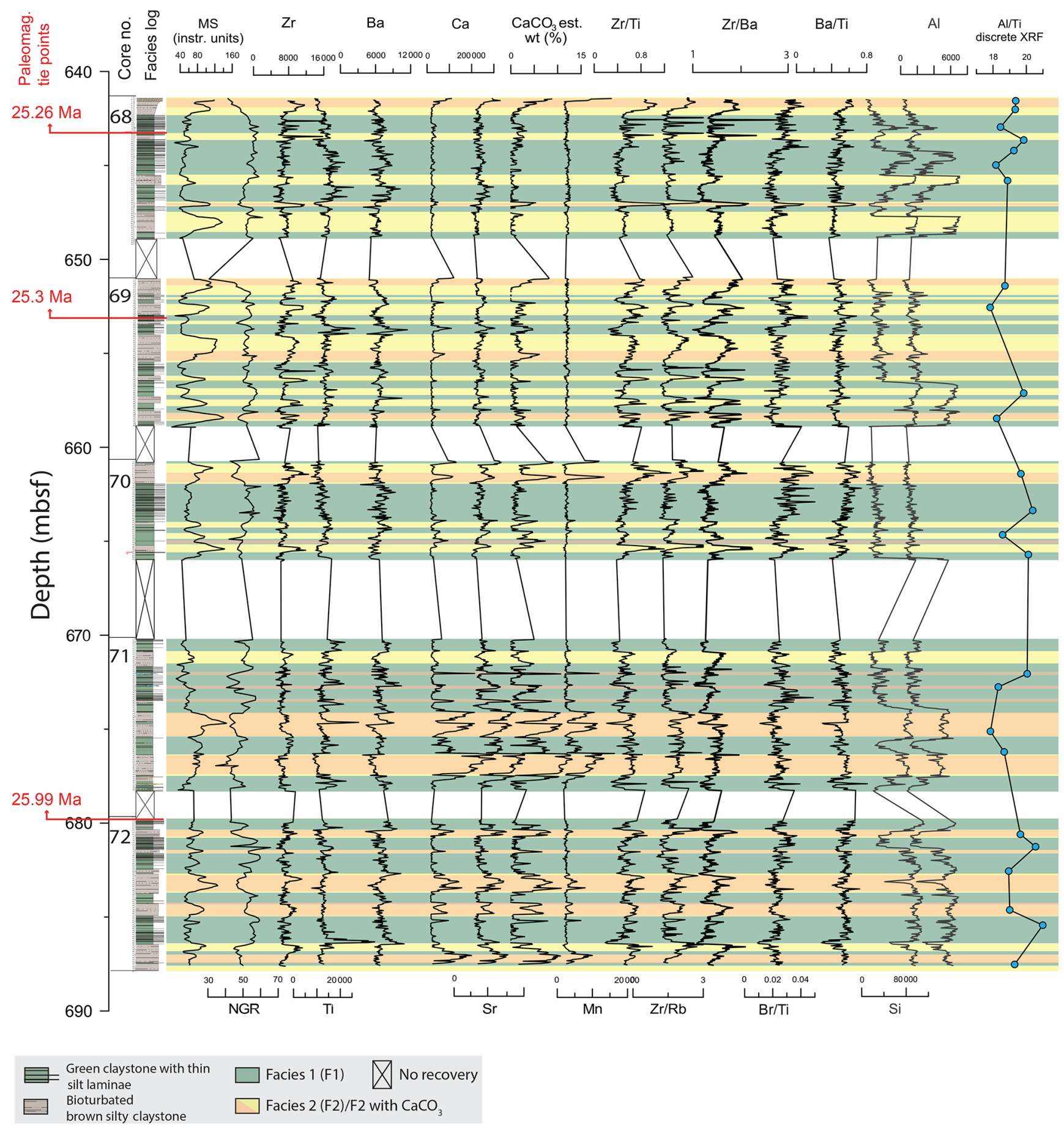

Figure 2. Magnetic susceptibility (MS) and natural gamma radiation (NGR) physical properties and selected X-ray fluorescence (XRF) data (in total counts) and elemental ratios plotted against the new detailed U1356 facies log between 689.4 and $641.4 \mathrm{~m}$ b.s.f.

(Fig. 2). The integration of our lithofacies analyses, with physical properties (MS), CT scans, and HR-SEM analyses, characterize an alternation between two main facies (Facies 1 and 2) (Figs. 2, 3, 4). Although these two facies were already visually identified on shipboard, our analyses allow us a more detailed characterization and interpretation of the de- positional environments and the processes involved in their development.

Facies 1 (F1) consists of slightly bioturbated greenish claystones with sparse (Fig. 3a) to common laminations (Figs. 2, 3a-f; Table 2). Laminae, as described on shipboard, vary from 0.1 to $1 \mathrm{~cm}$ thick and, based on nonquantitative 


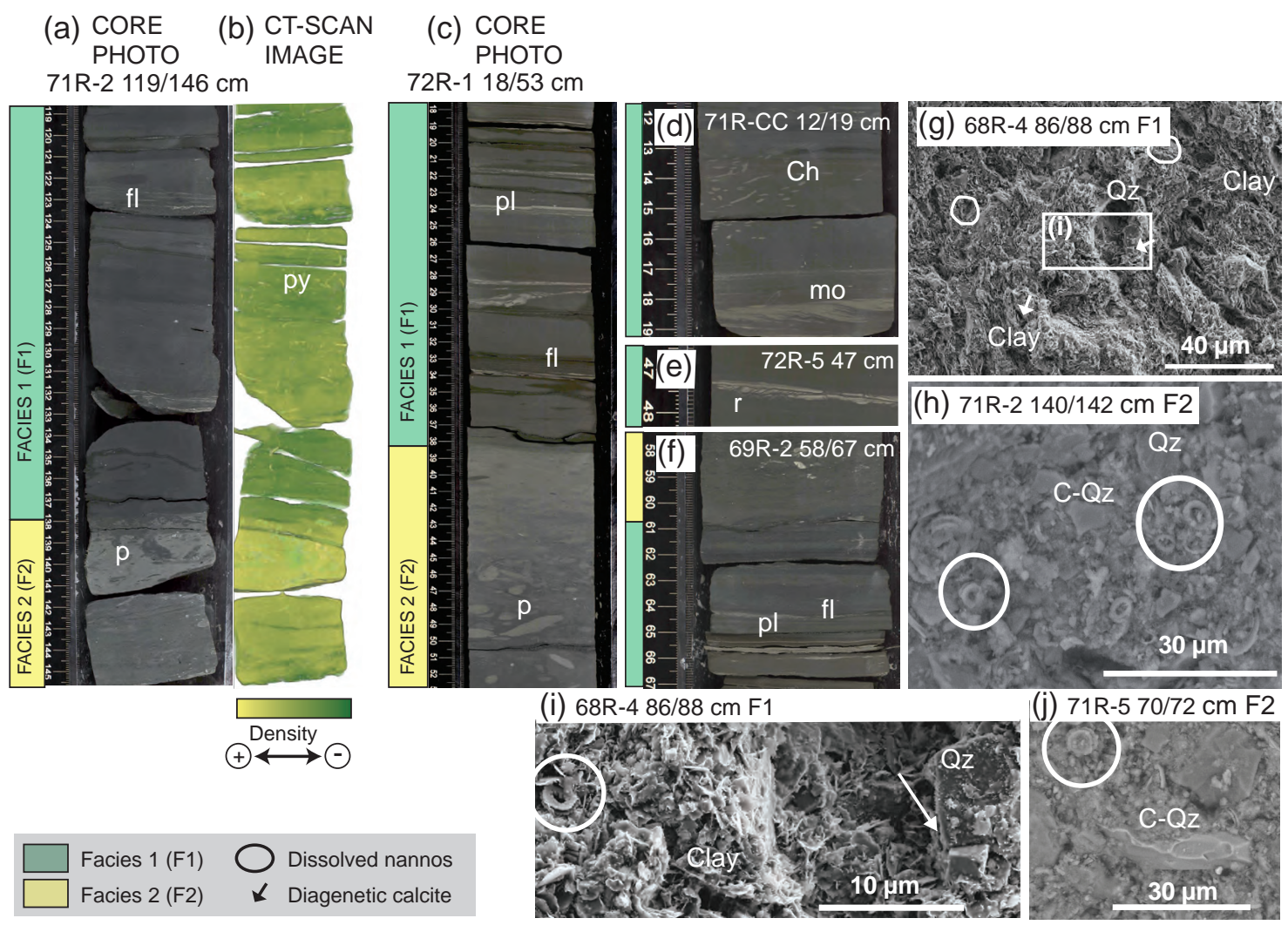

Figure 3. Detailed images, CT scans, and HR-SEM from Facies 1 (F1) and Facies 2 (F2). (a) Example of F1 taken from Core 71R-2 119/146 cm, showing faint laminations (fl) and bioturbation by Planolites (p). (b) CT-scan 3-D image of the same core interval; note the pyritized burrows (py). (c) Example of F2 taken from core 72R-1 18/53 cm). (d-f) Close-ups of laminations from F1: ripples (r), planar lamination (pl), and faint laminations (fl), with mud offshoots (mo). (d) Chondrites (Ch) bioturbation inside F1. (g) HR-SEM image of F1 (68R-4-86/88 cm) with detritic aspect and a mudstone clay matrix, quartz grains (Qz), diagenetic calcite (arrows), and dissolved coccoliths (circles). (h) HR-SEM image of F2 (71R-2 140/142 cm) silt-sized matrix and reworked calcareous nannofossils and conchoidal quartz grain (C-Qz). (i) Detail of dissolved coccoliths and diagenetic calcite mineral. (j) Detail of a dissolved and reworked calcareous nannofossils and a fractured conchoidal quartz (C-Qz).

smear slide observations, are composed of well-sorted silt to fine sand-size quartz grains (Escutia et al., 2011). Laminations can be planar and wavy, with ripple cross lamination structures (Escutia et al., 2011), and show faint internal truncation surfaces, mud offshoots, and internal erosional surfaces (Fig. 3a-f). HR-SEM analyses of the claystones show that the matrix is composed of clay-size particles and clay minerals (Fig. $3 \mathrm{~g}$, i). In addition, they show rare calcareous nannofossils that are partially dissolved (Fig. 3g, i). Authigenic carbonate crystals are also identified (Fig. 3i). Bioturbation in F1 is scarce, ichnofossils in the sediments are dominated mainly by Chondrites (Fig. 3d). CT scans also show the presence of Skolithos, with their vertical thin tubes filled with high-density material suggesting they are pyritized (Fig. 3b). Pyrite was also observed in shipboard smear slides in small abundances from the laminated facies in the studied interval (Escutia et al., 2011). Magnetic susceptibility values within the laminated facies are low, between 40 and 70 MS instrumental units (iu), with higher values when silt laminations are more abundant (Figs. 2, 4). NGR is anticorrelated with MS, with high values in F1 varying between 50 and 65 counts per second (cps) (Fig. 2).

Facies 2 (F2) is composed by light greenish grey, strongly bioturbated claystones and silty claystones (Figs. 2, 3; Table 2) with variable carbonate content varying between 5 and $16 \%$ based on our XRF analyses. No primary structures are preserved due to the pervasive bioturbation (Fig. 3a-c). Burrows are backfilled with homogeneous coarse material (silt/fine sand). Different types of ichnofossils are present with Planolites and Zoophycos being the most abundant (Fig. 3a, b). HR-SEM images show (1) silt-size grains containing quartz grains with conchoidal fractures in the corners and impact marks on the crystal faces, indicative of highenergy environments and (2) biogenic carbonate consisting of moderately to poorly preserved coccoliths, which exhibit dissolution of their borders, and to a minor degree detrital carbonate grains (Fig. 3h-j). A total of 13 carbonate-rich layers have been observed within the studied interval F2, and 


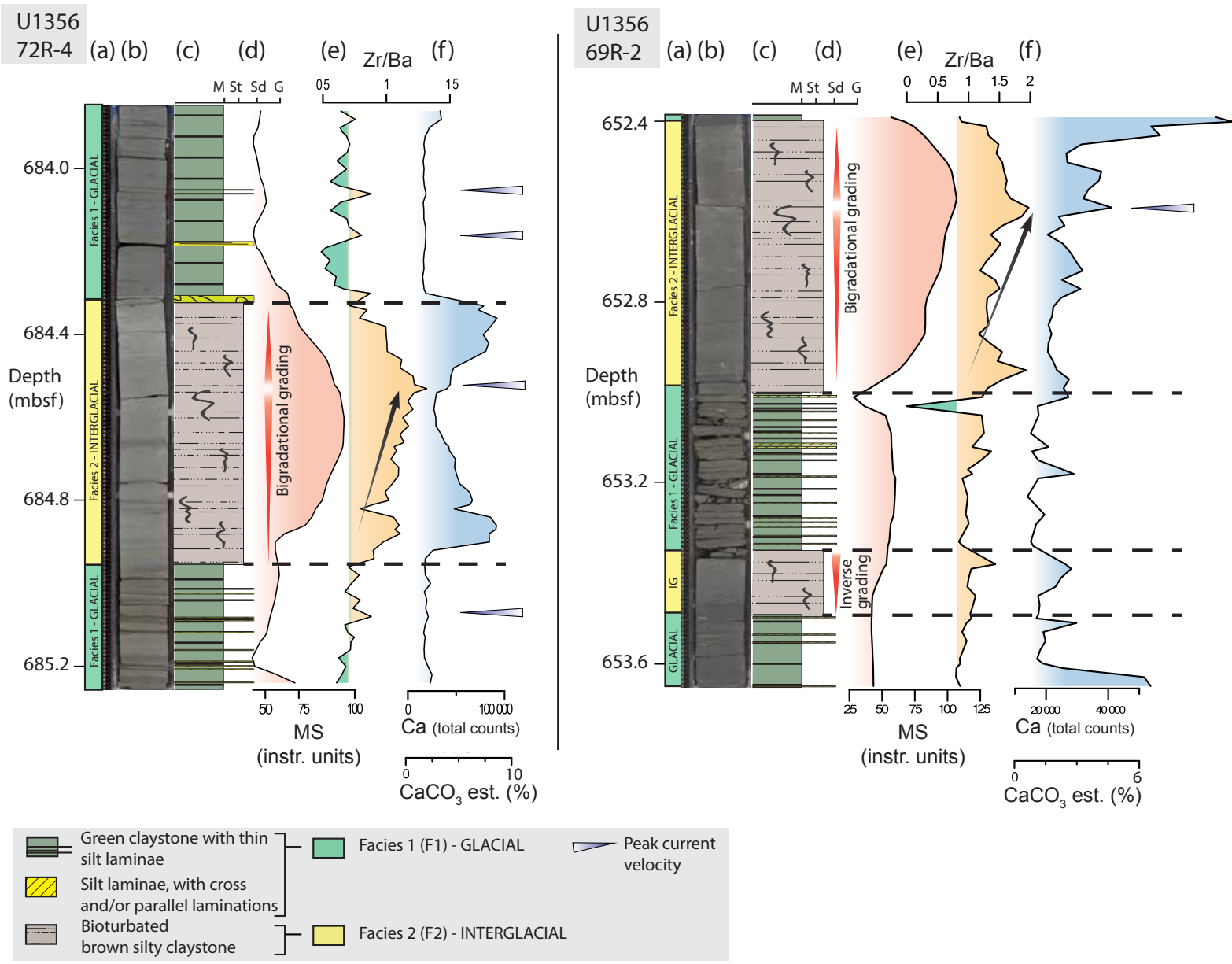

Figure 4. Detailed facies characterization of two representative sections using (a) interpreted Facies F1 and F2; a high-resolution digital image of the core sections (b), facies log (c), magnetic susceptibility (MS) (d), XRF Zr / Ba ratio (e), and XRF calcium counts (f).

they range in thickness from 10 to $110 \mathrm{~cm}$. Facies $2 \mathrm{CT}$-scan images show an increase in density (i.e., gradation towards lighter colors in the scan) towards the top of each bioturbated interval (Fig. 3b). MS values are higher in F2 compared to F1. Values vary from 50 to 150 instrumental units (iu) and exhibit an inverse grading or a bigradational-like morphology (Figs. 2, 4), while NGR is inversely correlated with minimum values occurring in F2 (between 35 and $55 \mathrm{cps}$ ) (Fig. 2).

Contacts between the two facies are sharp and apparently nonerosive, with minimal omission surfaces or lags (Figs. 3, 4). However, when bioturbation is present, gradual contacts in the transition from F1 to F2 also occur (Fig. 3b). Both sharp and transitional contacts are well imaged on the MS plots (Fig. 2).

In addition, where available, the CT-scan images confirm the shipboard and our own visual observations regarding the absence of outsized clasts and coarse sand grains in F1 and F2. Hauptvogel (2015), however, reports grains that are $>150 \mu \mathrm{m}$ in size (fine sand fraction) as IRD. He argues that grains of that size could only reach Site U1356 through ice rafting given the distance of the site to shore, unless they were delivered by gravity flows. Thick and coarse-grained mass transport deposits (MTDs) during the latest Oligocene at Site U1356 (Escutia et al., 2011), argue for coarse material being delivered to the site by gravity flows. In addition, fine sand grains to gravel-size clasts have been reported from channels on the lower continental rise off the Wilkes Land margin transported by gravity flows, including turbidity flows (Payne et al., 1972; Escutia et al., 2000; Busetti et al., 2003). Given that during the late Oligocene, Site U1356 is located on a low-relief levee of a submarine channel, one can expect delivery of fine-grained sand and even coarser sediment to the site. In any case, even if some background IRD is present in our record, we argue it is minimal compared to elsewhere in the core.

\subsection{Geochemistry}

Down-core changes in the log ratios of various elements have been plotted against the facies log (Figs. 2, 4). In addition, in order to determine geochemical element associations, we 
Table 2. Types of facies differentiated by physical, geochemical, and biological character and their interpretation in terms of sedimentary processes and paleoclimate.

\begin{tabular}{|c|c|c|c|}
\hline & & Facies 1 (F1) & Facies $2(\mathrm{~F} 2)$ \\
\hline \multicolumn{2}{|c|}{ Lithological description } & $\begin{array}{l}\text { Bioturbated green claystones with thin silt laminae } \\
\text { with planar and cross-bedded laminations }\end{array}$ & $\begin{array}{l}\text { Highly bioturbated, thicker pale-brown, } \\
\text { silty claystones }\end{array}$ \\
\hline \multirow{2}{*}{ Contacts } & Top & Gradual, bioturbated & Sharp \\
\hline & Bottom & Sharp & Gradual, bioturbated \\
\hline \multicolumn{2}{|l|}{ Bioturbation } & Sparse bioturbation; primary structures preserved & $\begin{array}{l}\text { Strongly bioturbated; massive; no primary } \\
\text { structures preserved }\end{array}$ \\
\hline \multicolumn{2}{|l|}{ Nannos } & Barren to rare & $\begin{array}{l}\text { Barren to variable abundance and } \\
\text { preservation }\end{array}$ \\
\hline \multicolumn{2}{|l|}{ IRD } & No & No \\
\hline \multicolumn{2}{|c|}{ Magnetic susceptibility (MS) } & Low in claystones and high in silty laminations & High \\
\hline \multirow{3}{*}{$\begin{array}{l}\text { XRF-scanner } \\
\text { element } \\
\text { concentration }\end{array}$} & $\mathrm{Zr}$ & Low in claystones and high in silty laminations & High (max. values on top) \\
\hline & $\mathrm{Ba}$ & High (max. values on bottom) & Low \\
\hline & $\mathrm{Ca}$ & No & Variable, low to high \\
\hline \multicolumn{2}{|c|}{ Formation process } & Bottom currents of fluctuating intensities & $\begin{array}{l}\text { Bottom currents with higher velocity and } \\
\text { constant flux }\end{array}$ \\
\hline \multicolumn{2}{|c|}{ Facies interpretation } & $\begin{array}{l}\text { Cold periods; supply of terrigenous by density cur- } \\
\text { rent flows, reworked by bottom currents }\end{array}$ & $\begin{array}{l}\text { Well-oxygenated deep-sea sedimentation; } \\
\text { warm periods with reworking of sediments } \\
\text { by bottom currents }\end{array}$ \\
\hline
\end{tabular}

performed a Pearson correlation coefficient analysis of major elements on the whole XRF-scanner dataset (Table 3). This analysis highlights two main groups that are used as proxies for terrigenous (i.e., $\mathrm{Zr}, \mathrm{Ti}, \mathrm{Rb}, \mathrm{Ba}$ ) vs. biogenic (i.e., $\mathrm{Ca}=$ carbonate) sedimentation.

Titanium (Ti), Zirconium (Zr), and Rubidium $(\mathrm{Rb})$ are primarily derived from terrigenous sources, where Ti represents the background terrigenous input. During sediment transport $\mathrm{Zr}, \mathrm{Rb}$, and $\mathrm{Ti}$ tend to become concentrated in particular grain-size fractions due to the varying resistance of the minerals in which these elements principally occur. $\mathrm{Zr}$ tends to become more concentrated in fine sand and coarse-silt fractions, $\mathrm{Ti}$ in somewhat finer fractions, and $\mathrm{Rb}$ principally in the clay-sized fraction (Veldkamp and Kroonenberg 1993; Dypvik and Harris 2001). The lack of correlation between $\mathrm{Zr}$ and $\mathrm{Ti}$ (Fig. 2; Table 3) implies that they are settled in different minerals and processes. The $\mathrm{Zr} / \mathrm{Rb}$ ratio has been applied as a sediment grain-size proxy in marine records (Schneider, et al., 1997; Dypvik and Harris 2001; Croudace et al., 2006; Campagne et al., 2015). Zr / Al has been interpreted as an indicator for the accumulation of heavy minerals due to bottom currents (Bahr et al., 2014). In our cores, $\mathrm{Zr} / \mathrm{Rb}$ and $\mathrm{Zr} / \mathrm{Ti}$ ratios have a near-identical variability down-core (Fig. 2). We utilize the high-amplitude Zr / Ti signal in our records as an indicator of larger grain size and current velocity (Fig. 2). The $\mathrm{Zr} / \mathrm{Ti}$ ratio varies between 0.1 and 1 and exhibits maximum values within $\mathrm{F} 2$ showing an increasing upwards or bigradational patterns (Fig. 2). Although minimum $\mathrm{Zr}$ values (cps) are found in F1, laminations with coarser-grained sediment within this claystone facies are also characterized by elevated $\mathrm{Zr}$ values similar to those in $\mathrm{F} 2$ (Figs. 3, 4; Table 3). The $\mathrm{Zr} / \mathrm{Ti}$ pattern is positively correlated with magnetic susceptibility throughout the studied interval (Fig. 2).

The $\mathrm{Zr} / \mathrm{Ti}, \mathrm{Zr} / \mathrm{Rb}$, and $\mathrm{Zr} / \mathrm{Ba}$ ratios covary characterizing the laminations within $\mathrm{F} 1$ and the alternation between F1 and F2 by defining the contacts between them (Figs. 2, 4). They also mark the coarsening upwards or bigradational tendency in F2 (Fig. 4). Of the three ratios, the $\mathrm{Zr} / \mathrm{Ba}$ ratio is the one that highlights these patterns best (Figs. 2, 4).

Barium (Ba) is present in marine sediments mainly in detrital plagioclase crystals and in the form of barite $\left(\mathrm{BaSO}_{4}\right.$; Tribovillard et al., 2006). In the studied sediments, Ba and Ti have a correlation factor of $r^{2}=0.66$ (Table 3 ), which is taken to indicate that Barium is predominantly present as a constituent of the continental terrigenous fraction and/or that biogenic barite was sorted by bottom currents. Ba has maximum values (10000 total counts) at the base of $\mathrm{F} 1$ and decreases upwards in a sawtooth pattern, reaching minimum concentrations within F2 (5000 total counts) (Fig. 2; Table 3). The detrital fraction of $\mathrm{Ba}$ in the open ocean has been used in other studies as a tracer of shelf waters (Moore and Dymond, 
Table 3. R Pearson Linear correlation between XRF-scanner elements.

\begin{tabular}{lrrrrrrrrrr}
\hline & $\mathrm{MS}$ & $\mathrm{S}$ & $\mathrm{Ca}$ & $\mathrm{Ti}$ & $\mathrm{Mn}$ & $\mathrm{Fe}$ & $\mathrm{Br}$ & $\mathrm{Rb}$ & $\mathrm{Zr}$ & $\mathrm{Sr}$ \\
\hline $\mathrm{S}$ & -0.214 & & & & & & & & & \\
$\mathrm{Ca}$ & 0.226 & -0.122 & & & & & & & & \\
$\mathrm{Ti}$ & -0.212 & 0.620 & -0.290 & & & & & & & \\
$\mathrm{Mn}$ & 0.151 & -0.121 & 0.858 & -0.246 & & & & & & \\
$\mathrm{Fe}$ & 0.0419 & 0.0449 & -0.396 & 0.510 & -0.324 & & & & & \\
$\mathrm{Br}$ & -0.297 & 0.111 & -0.438 & 0.118 & -0.363 & 0.056 & & & & \\
$\mathrm{Rb}$ & -0.282 & 0.036 & -0.576 & 0.286 & -0.489 & 0.455 & 0.493 & & & \\
$\mathrm{Zr}$ & 0.480 & -0.164 & -0.036 & -0.099 & -0.058 & -0.055 & 0.102 & 0.067 & & \\
$\mathrm{Sr}$ & 0.186 & 0.006 & 0.871 & -0.074 & 0.677 & -0.345 & -0.303 & -0.515 & 0.040 & \\
$\mathrm{Ba}$ & -0.290 & 0.339 & -0.234 & 0.662 & -0.210 & 0.354 & 0.343 & 0.402 & 0.018 & 0.039 \\
\hline
\end{tabular}

1991; Abrahamsen et al., 2009; Roeske, 2011), and the Ba record is also affected by current intensity in other depositional contourite systems (Bahr et al., 2014) preventing its use as paleo-productivity proxy in environments dominated by contour currents.

Variations in $\mathrm{Ca}, \mathrm{Mn}$, and $\mathrm{Sr}$ are strongly intercorrelated (Fig. 2) with $\mathrm{r}^{2}>0.87$ (Table 3). Biogenic calcite precipitated by coccoliths and foraminifera have greater $\mathrm{Sr}$ concentration than inorganically precipitated calcite or dolomite (Hodell et al., 2008). The positive $\mathrm{Ca}$ and $\mathrm{Sr}$ correlation could therefore potentially be used to differentiate between terrigenous $\mathrm{Ca}$ sources (e.g., feldspars and clays) and biogenic carbonates (e.g., Richter et al., 2006; Foubert and Henriet, 2009; Rothwell and Croudace, 2015). Based on these observations, we interpret the $\mathrm{Ca}$ in our sediments as being mainly of biogenic origin $\left(\mathrm{CaCO}_{3}\right)$. This interpretation is supported by HR-SEM images taken from carbonate-rich intervals of F2, which show abundant coccoliths (Fig. 3d). Peaks in Ca in our record (Fig. 2) coincide with the carbonate-rich layers listed in the previous section. Additional peaks in the record may indicate carbonate-rich layers that we have been unable to identify visually.

In order to estimate the $\mathrm{CaCO}_{3}$ content continuously throughout the studied interval we use a calibration $\left(r_{U 1356}^{2}=0.81\right)$ between the natural logarithm $(\ln )$ of the $\mathrm{Ca} / \mathrm{Ti}$ ratio $(\ln (\mathrm{Ca} / \mathrm{Ti}))$ from the XRF core scanner data and the XRF discrete $\mathrm{CaCO}_{3}$ measurements (weight \%) from Site U1356 as applied in other studies (Zachos et al., 2004; Liebrand et al., 2016) (Fig. 5). " $\mathrm{CaCO}_{3}$ est." is used throughout the text to refer to carbonate content estimated by the $\ln (\mathrm{Ca} / \mathrm{Ti})$ ratio. $\mathrm{CaCO}_{3}$ est. concentrations are generally low (between 0 and $16 \%$ ). Carbonates are mostly present in F2, varying between 5 and $16 \%$, although small contents (from 0 to $5 \%$ ) can be seen in the intervals of $\mathrm{F} 1$ with scarce laminations (Fig. 4). $\mathrm{CaCO}_{3}$ est. peaks in some intervals have a particular morphology producing a double peak in the beginning and/or the end of bioturbated F2 (Figs. 2, 4).

$\mathrm{Mn}$ (II) is soluble under anoxic conditions and precipitates as $\mathrm{Mn}(\mathrm{IV})$ oxyhydroxides under oxidizing conditions (Tribovillard et al., 2006). Manganese is frequently remo-

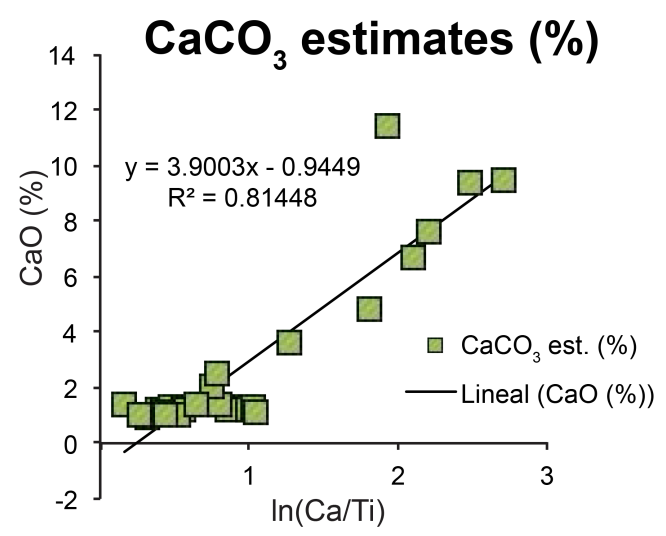

Figure 5. Linear correlation between $\mathrm{CaO} \%$ (discrete XRF) and $\ln (\mathrm{Ca} / \mathrm{Ti})(\mathrm{XRF}$ scanner) values in order to estimate carbonate contents $\left(\mathrm{CaCO}_{3}\right.$ est. \%).

bilized to the sedimentary pore fluids under reducing conditions. Dissolved Mn can thus migrate in the sedimentary column and (re)precipitate when oxic conditions are encountered (Calvert and Pedersen, 1996). As such, large Mn enrichments primarily reflect changing oxygen levels at the sediment-water interface (Jaccard et al., 2016). The strongly correlated peaks of $\mathrm{Mn}$ and $\mathrm{Ca}$ (Fig. 2; Table 3) suggest that at least some of the $\mathrm{Mn}$ is present in the studied interval as Mn carbonates and/or Mn oxyhydroxides under the oxic sediment-water interphase (Calvert and Pedersen, 1996, 2007; Tribovillard et al., 2006).

$\mathrm{Br} / \mathrm{Ti}$ has been previously used as an indicator of organic matter in sediments (e.g., Agnihotri et al., 2008; Ziegler et al., 2008; Bahr et al., 2014). Br / Ti in our record shows generally low values (Fig. 2), most likely because the organic matter content in both facies types is relatively low $(<0.5 \%$, Escutia et al., 2011). However, it exhibits some variability ( 0.01 to $0.05 \mathrm{Br}$ / Ti ratio) within the two facies, with higher ratio values in F1. Darker colored sediments in F1 are in agreement with these higher $\mathrm{Br} / \mathrm{Ti}$ values inside $\mathrm{F} 1$.

In addition to the elemental analyses of the XRF-scanned data, we use the detrital $\mathrm{Al} / \mathrm{Ti}$ ratio in discrete XRF bulk 
sediment samples to reflect changes in terrigenous provenance (Kuhn and Diekmann, 2002; Scher et al., 2015). The $\mathrm{Al} / \mathrm{Ti}$ ratio varies between 17 and 21, with the highest values found within F1 and the lowest in F2 (Fig. 2).

\subsection{Spectral analysis}

To detect periodical signals, a spectral analysis of time series was performed on the $\mathrm{Zr} / \mathrm{Ba}$ and other elemental proxies (i.e., $\mathrm{Ba}, \mathrm{Zr} / \mathrm{Ti}, \mathrm{CaCO}_{3}$, magnetic susceptibility) using the Astrochron R software (Meyers, 2014; Figs. 6, S3-S10).

Multiple-taper spectral analysis method (MTM) in $\mathrm{Zr} / \mathrm{Ba}$ show a clear and statistically significant $(>90 \%)$ cyclicity every $2 \mathrm{~m}\left(0.5\right.$ cycles $\left.\mathrm{m}^{-1}\right)$ and at $4.67 \mathrm{~m}^{\left(0.21 \text { cycles }^{-1}\right)}$ and a less significant one $(>80 \%)$ at $1 \mathrm{~m}\left(0.94\right.$ cycles $\left.^{-1}\right)$ (Fig. S3). On the basis of a linearly calculated sedimentation rate between the two extreme tie points (Table 1), we obtained a sedimentation rate of approximately $5 \mathrm{~cm} \mathrm{kyr}^{-1}$. Within this sedimentation rate, the 0.5 cycles $\mathrm{m}^{-1}$ peak corresponds to the $41 \mathrm{kyr}$ obliquity frequency, and the 0.21 and 0.94 cycles $\mathrm{m}^{-1}$ correspond to the 95 and $21 \mathrm{kyr}$ shorter eccentricity periods and precession frequencies, respectively.

After an initial analysis, we ran an evolutive harmonic analysis (EHA) (Astrochron; Meyers, 2014) with three data tapers for the untuned $\mathrm{Zr} / \mathrm{Ba}$ in depth domain with $2 \mathrm{~cm}$ resolution (Fig. S3). The statistical significance of spectral peaks was tested relative to the null hypothesis of a robust red noise background (AR(1) modeling of median smoothing) at a confidence level of $95 \%$ (Mann and Lees, 1996). Despite a short core gap in the middle of the time series, obliquity (41 kyr) dominates throughout the time series (Fig. 6). The sedimentation rates obtained by this method vary between 4.6 and $5.4 \mathrm{~cm} \mathrm{kyr}^{-1}$ for the studied section, similar to those obtained with linearly calculated sedimentation rates. Additionally, the Nyquist frequency for $\mathrm{Zr} / \mathrm{Ba}$ data is $1 \mathrm{~m}^{-1}(0.5 \mathrm{kyr})$, which implies the site is sampled sufficiently to resolve precessional-scale variations; however, core gaps prevent identification of long eccentricity cycles (Fig. S6). Time series were anchored to the more robust paleomagnetic tie point in the U1356 age model, which is $25.99 \mathrm{Ma}$ at $678.78 \mathrm{~m}$ b.s.f. (Fig. S7).

Apart from obliquity, spectral analyses of the tuned age model reveal an alignment of the eccentricity and precession bands (Figs. 6, S8). For example, a marked cyclicity at the obliquity periods of $41 \mathrm{kyr}$ is seen at $\mathrm{Ba}$ and $\mathrm{Zr} / \mathrm{Ti}$ (99\% confidence); eccentricity at $100 \mathrm{kyr}$ and precession at $20 \mathrm{kyr}$ (95\% confidence) are also seen (Fig. S9). We also observe coherent power above the $90 \%$ significance level at $\sim 54$ and $\sim 29$ kyr periods, which are secondary components of obliquity. The anchored age model provides an unprecedented $500 \mathrm{yr}$ resolution $(2.5 \mathrm{~cm}$ sampling) of the data during the late Oligocene. Orbital frequencies were tested in each core section individually in the $\mathrm{Zr} / \mathrm{Ba}$ dataset on the depth scale in order to assure that cyclicity is not an artifact related to the gaps in the series (Fig. S10).

\section{Discussion}

Based on the integration of the facies characterized on the basis of sedimentological data (visual core description, facies analysis, CT scans, HR-SEM), physical properties (magnetic susceptibility, NGR), and geochemical data (XRF), we provide for the late Oligocene interval (26 to $25 \mathrm{Ma}$ ) (1) a new glacial-interglacial sedimentation model for the distal glaciomarine record in the Wilkes Land margin dominated by bottom current reworking of both glacial and interglacial deposits; (2) insights into the configuration of the ice sheet in this sector of the east Antarctic margin; (3) changes in the paleoceanographic glacial-interglacial configuration; and (4) evidence for orbital forcing of the glaciomarine glacialinterglacial sedimentation at Site U1356.

\subsection{Glacial and interglacial contourite sedimentation off Wilkes Land}

Laminated claystones (F1) from Site U1356 were originally interpreted by the shipboard science team to have formed during glacial times relating to variations in bottom current strength and fine-grained terrigenous supply. Conversely, the bioturbated claystones and micritic limestones (F2) were interpreted as resulting from mostly hemipelagic sedimentation during interglacial times (Escutia et al., 2011). Alternations between laminated deposits and bioturbated hemipelagic deposits, similar to those in F1 and F2, have been previously reported to characterize Pleistocene and Pliocene glacial-interglacial continental rise sedimentation, respectively, on this sector of the Wilkes Land margin (Escutia et al., 2003; Patterson et al., 2014). Gravity flows (mainly turbidity flows) are the dominant process during glacial times, resulting in laminated deposits. Interglacial sedimentation is dominated by hemipelagic deposition with higher opal and biogenic content (Escutia et al., 2003; Busetti et al., 2003). Erosion and redeposition of fine-grained sediment by bottom contour currents has also been reported as another important process during Pleistocene and Plio-Quaternary interglacials (Escutia et al., 2002, 2003; Busetti et al., 2003).

Despite being sparse, the occurrence of bioturbation in our laminated sediments in F1, which slightly affects both claystones and silt laminations, indicates slow and continuous sedimentation. This is not consistent with instantaneous turbidite deposition, which would be expected at the Site U1356 located on the left low-relief levee of a contiguous channel during the late Oligocene. It is, however, consistent with fine-grained turbidite overbank deposits being consequently entrained by bottom currents. Silt layer sedimentary structures similar to those described by Rebesco and Camerlenghi (2008) and Rebesco et al. (2014) indicate that there is current reworking of the sediments. For example, silt layers can be continuous or discontinuous with wavy and irregular morphologies, and within layers, sedimentary structures such as cross laminations are common (Fig. 3c-f). Within the 


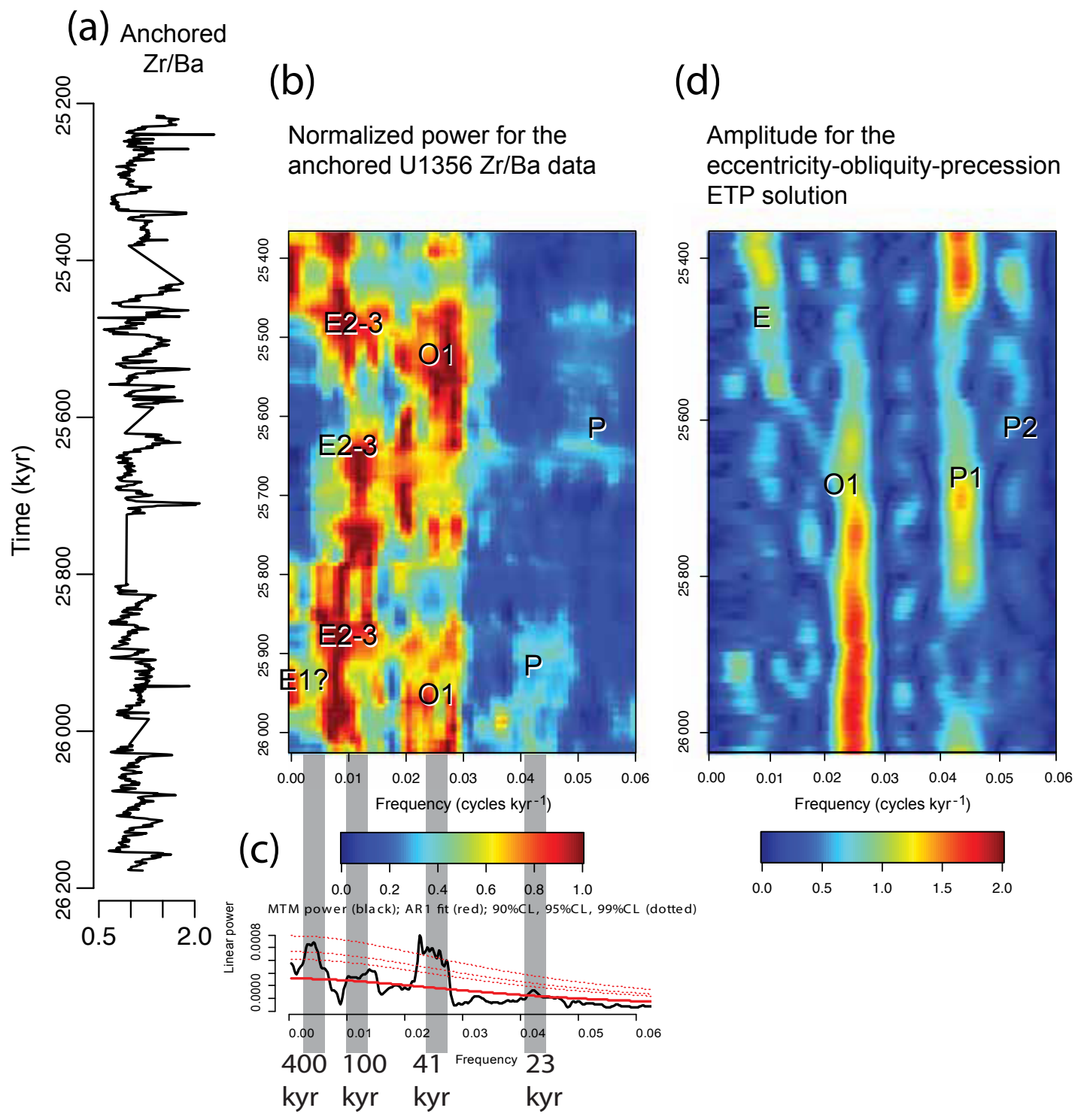

Figure 6. Spectral analysis results of the $\mathrm{Zr}$ / Ba obliquity tuned and anchored data. (a) $\mathrm{Zr} / \mathrm{Ba}$ ratio tuned with Astrochron (Meyers, 2014) and anchored to the top of the C8n.2n (o) chron. (b) EHA and (c) MTM spectral analysis on Zr / Ba tuned data. EHA normalized power with $300 \mathrm{kyr}$ window with discrete prolate spheroidal sequence (DPSS) tapers. (d) EHA amplitude for the eccentricity, obliquity (tilt), and precession (ETP) solution (Laskar et al., 2004) calculated for the same period of time with 3DPSS tapers and 200 kyr window.

cross laminae, mud offshoots, and internal erosional surfaces are distinctive features of fluctuating currents where successive traction and suspension events are superimposed, indicating bottom current sedimentation as the principal process for the F1 laminated claystones (Shanmugam et al., 1993; Stow, 2002). Based on these observations, we interpret F1 as glacial laminated muddy contourites following the classification of Stow and Faugères (2008). The F1 sedimentary structures suggest bottom currents with fluctuating intensities, which result in laminations and internal structures forming during peak current velocities (Lucchi and Rebesco, 2007; Martín-Chivelet et al., 2008; Rebesco et al., 2014). Lam- inated, fossil-barren, glaciogenic deposits, consistent with those of Facies F1, have been observed on younger sedimentary sections in glaciated margins and interpreted as contour current-modified turbidite deposits and as muddy contourites (Anderson et al., 1979; Mackensen et al., 1989; Grobe and Mackensen, 1992; Pudsey, 1992; Gilbert et al., 1998; Pudsey and Howe, 1998; Pudsey and Camerlenghi, 1998; Anderson, 1999; Williams and Handwerger, 2005; Lucchi and Rebesco, 2007, Escutia et al., 2009). This particular type of contourite facies is associated with glaciomarine deposition during times of glacial advance and has been interpreted as resulting from unusual, climate-related, environmental con- 
ditions of suppressed primary productivity and oxygen-poor deep waters (Lucchi and Rebesco, 2007).

Bioturbated sediments in F2 were previously interpreted as interglacial hemipelagic deposits (Escutia et al., 2011). In this study, we interpret F2 as hemipelagic and overbank deposits reworked by bottom currents. The coarser grain size in F2 compared to F1 (silty clay matrix as seen in HRSEM, Fig. $3 g-j$ ), the distribution of heavy minerals as indicated by the $\mathrm{Zr} / \mathrm{Ba}$, and the elevated values of the magnetic susceptibility record with a bigradational pattern within the facies (Figs. 2, 4) support the notion that interglacial sediments of F2 have been heavily modified by bottom currents. Hemipelagic sediments are expected to be homogeneous in terms of grain size and grading is not expected. Current winnowing of hemipelagic deposits and the removal of the fine-grained fraction can produce the higher accumulation of heavy (indicated by the $\mathrm{Zr}$ ) and ferromagnetic (indicated by MS) minerals observed in F2 compared to F1 (Fig. 2; Table 2). High MS values result from stronger bottom current deposition and/or increased terrigenous input (e.g., Pudsey, 2000; Hepp, 2007). Also, bigradational trends have been previously described in contourite sediments and interpreted as recording an increase followed by a decrease in the current velocities (e.g., Martín-Chivelet et al., 2008). The bigradational patterns in the $\mathrm{Zr} / \mathrm{Ba}$ and MS plots (Figs. 2, 4) are therefore interpreted as depicting a constant and smooth increase followed by a decrease in current velocity with little gradual changes in flow strength. In addition, the presence of grains of quartz with conchoidal fractures and reworked coccolithophores with signs of dissolution (Fig. 3h, j) support the reworking of background hemipelagic and turbidite overbank sediments by bottom currents in a high-energy environment (Damiani et al., 2006). Following the classification by Stow and Faugères (2008), we interpret that F2 has more silty massive contourites resulting from higher and more constant bottom current velocity compared to F1.

Transitions between the F1 and F2 facies are characterized by glacial-to-interglacial contacts that may be sharp or diffuse due to bioturbation and are characterized by a gradual change in physical and geochemical sediment parameters (Figs. 3, 4; Table 3). Interglacial-to-glacial contacts (F2 to F1), on the other hand, are characterized by an apparently non-erosional sharp lithological boundary. The sharp lithological boundaries between interglacial to glacial transitions can be explained by maximum current intensities achieved at the end of the interglacials (Shanmugam, 2008; Rebesco et al., 2014).

\subsection{Ice sheet configuration during the warm late Oligocene}

Early Oligocene and post-mid Miocene climate transition sediments from Site U1356 contain granule and larger clasts ( $>2 \mathrm{~mm}$ ) interpreted as IRD (Escutia et al., 2011; Sangiorgi et al., 2018; Fig. S1). In addition, dinocyst assemblages in- dicate the presence of sea ice (Houben et al., 2013). Based on this, one could expect the site to be within the reach of icebergs calving from an expanded ice sheet grounded at the coast or beyond in the late Oligocene. This is supported by Pliocene-Pleistocene sedimentary sections in adjacent continental rise sites containing IRD (Escutia et al., 2011; Patterson et al., 2014). In addition to the paucity of IRD in our studied interval, the absence of sea-ice-loving species Selenopemphix antarctica, and abundant gonyaulacoid phototrophic dinocysts suggest warm to temperate surface waters (Bijl et al., 2018b). A sea-ice-free scenario during the late Oligocene is also supported by elevated sea surface temperatures (i.e., average summer temperatures are $\sim 19^{\circ} \mathrm{C}$ ) based on biomarker sea surface temperatures TEX $_{86}$ data in Hartman et al., 2018). Furthermore, the presence of in situ terrestrial palynomorphs suggests that during the late Oligocene, margins nearby were in part free of ice sheets and covered by a cool to temperate vegetation with trees and shrubs (Salzmann et al., 2016; Strother et al., 2017). All these observations suggest a reduced ice sheet and partly ice-free margins in the Wilkes margin during the late Oligocene.

These observations are consistent with the iceberg survivability modeling in the Southern Ocean for the warm Pliocene intervals, which shows the distance that icebergs could travel before melting was significantly reduced (Cook et al., 2014). Warm Pliocene summer sea surface temperatures up to $6{ }^{\circ} \mathrm{C}$ warmer than today during interglacials and prolonged Pliocene warm intervals have been reported in the Ross Sea (e.g., Naish et al., 2009; McKay et al., 2012) and other locations around Antarctica (Whitehead and Bohaty, 2003; Whitehead et al., 2005; Escutia et al., 2009; Bart and Iwai, 2012). Contrary to what we observe in our late Oligocene record and in the Miocene Climatic Optimum (Sangiorgi et al., 2018), abundant IRD was delivered to continental rise sites adjacent to Site U1356 during the warm Pliocene (Escutia et al., 2011; Patterson et al., 2014). This was interpreted by Cook et al. (2017) to suggest that a considerable number of icebergs (iceberg armadas) had to be produced in order to reach the site under these warm Pliocene conditions. We argue that the lack of IRD delivery to Site U1356 during the studied warm late Oligocene interval can result from the different WSB late Oligocene paleotopographic setting. Paleo-topographic reconstructions from 34 Myr ago (Wilson et al., 2012) and the early Miocene (Gasson et al., 2016) show the WSB to be an area of lowlands and shallow seas in contrast to the overdeepened marine basin that it is today (Fretwell et al., 2013). This paleo-topographic configuration would have precluded widespread marine ice sheet instability during the Oligocene. This difference is important, as an ice sheet grounded on an overdeepened continental shelf can experience marine ice sheet instability, a runaway process relating to ice sheet retreat across a reverse slope continental shelf (Weertman, 1974), which is proposed to be a driver for retreat of the EAIS in the WSB during the warm Pliocene (Cook et al., 2013). Conversely, a shal- 
lower continental shelf allows for the potential expansion of grounded ice sheets into the marine margin during warmerthan-present climates (Wilson et al., 2012), and thus direct records are required to assess the climate threshold for such an advance.

In comparison to the distal U1356 Wilkes Land margin record, the Ross Sea Embayment ice proximal sediments obtained by the CRP contain Oligocene to Early Miocene palynomorphs, foraminifera, and clay assemblages that point to a progressive decrease in fresh meltwater, cooling, and intensifying glacial conditions (Leckie and Webb, 1983; Hannah et al., 2000, 2001; Raine and Askin, 2001; Thorn, 2001; Ehrmann et al., 2005; Barrett, 2007). Therefore, the coastal CRP sediment record does not support a significant loss of ice or warming during the late Oligocene (Barrett, 2007). The high sedimentation rates during the late-Oligocene-earlyMiocene recorded at Deep Sea Drilling Project (DSDP) Site 270 were interpreted as reflecting turbid plumes of glaciomarine sediments derived from polythermal-style glaciers or ice sheets that were calving into an open Ross Sea, without an ice shelf (Kemp and Barrett, 1975). In addition, seismic data indicate that during the late to mid-Oligocene widespread expansion of a marine-based ice sheet onto the outer Ross Sea shelf did not take place, but instead glaciers and ice caps drained from local highs and advanced only into shallow marine areas rather than there being a whole-scale marine ice sheet advance (Brancolini et al., 1995; De Santis et al., 2013; Bart and De Santis, 2012).

Combined, this evidence suggests that during the late Oligocene, marine-terminating glaciers, ice caps, and glaciers persisted along the Transantarctic Mountain front reaching the Ross Sea coastal areas, but it may have been more confined within a warmer WSB margin. This is also supported by vegetation reconstructions derived from fossil pollen from both margins, which, for the middle Miocene and late Oligocene, indicate higher terrestrial temperatures and more tree taxa at Wilkes Land (Salzmann et al., 2016; Sangiorgi et al., 2018) than the Ross Sea (Askin and Raine, 2000; Prebble et al., 2006). This is consistent with the ice sheet modeled configuration for Miocene topographies with $\mathrm{CO}_{2}$ scenarios of 500-840 ppm (Gasson et al., 2016; Levy et al., 2016; Fig. 7).

\subsection{Paleoceanographic implications}

Sediment physical properties and geochemical signatures of F1 and F2 are here related to changes in bottom-watersediment interphase oxygenation/ventilation during successive glacial and interglacial periods (Table 2). We interpret that these changes are linked to shifts in water masses driven by a north-south displacement of the position of the westerlies and associated changes in the intensity of frontal mixing or location of the polar front and Antarctic Divergence (Fig. 7). Based on our observations, we propose a model to explain the interpreted changes in bottom water conditions at
Site U1356 during successive glacial and interglacial times (Fig. 7).

\subsubsection{Glacial paleoceanographic configuration}

The Chondrites-like bioturbation with pyrite infilling the tubes of Skolithos within F1 (Fig. 3b, d) has previously been reported to characterize low-oxygen conditions at the watersediment interphase (Bromley and Ekdale, 1984). In addition, pyritized diatoms are present throughout the Oligocene section of this site but are found preferentially inside F1. The presence of pyritized diatoms was interpreted during Expedition 318 as indicating a prolific production and syn-sedimentary diagenesis in a restricted circulation (lowoxygen) environment, mainly during glacial periods (Escutia et al., 2011). Reducing conditions in the sediment also help to preserve primary sedimentary structures of the silt layers in F1 because bioturbation is limited. Higher amounts of organic matter in $\mathrm{F} 1$ compared to $\mathrm{F} 2$ are suggested by increased values of the $\mathrm{Br} / \mathrm{Ti}$ ratio (Fig. 2). The higher organic content most likely produces a poorly ventilated environment with near-reducing conditions at the water-sediment interphase, where pyrite can precipitate (Tribovillard et al., 2006). In spite of this, total oxygen depletion did not occur as indicated by the palynomorphs good preservation within F1 (Bijl et al., 2018b).

Low MS values such as those recorded within F1 (Fig. 4; Table 2) have been reported around Antarctica and attributed to magnetic mineral dissolution caused by dilution and/or primary diagenesis effects on the sediments due to the higher concentration in organic matter or to changing redox conditions (Korff et al., 2016). Several authors have postulated that oxygen-depleted Antarctic Bottom Water (AABW) occupying the abyssal zones of the oceans can change the redox conditions in the sediment, trapping and preserving dissolved and particulate organic matter and, consequently, reducing and dissolving both biogenic and detrital magnetite (Florindo et al., 2003; Hepp et al., 2009; Korff et al., 2016). At present, Site U1356 is influenced by AABW forming in the adjacent Wilkes Land shelf (Orsi et al., 1999; Fukamachi et al., 2000) and in the Ross Sea, spilling over to the Wilkes Land continental shelf (Fukamachi et al., 2010) (Fig. 1). Our records suggest a reduced continental ice sheet in the eastern Wilkes Land margin and a reduced sea ice presence compared to today (Bijl et al., 2018b). Under these conditions, bottom water formation and downwelling can still occur (with or without the presence of sea ice) as a result of density contrasts related to seasonal changes in surface water temperature and salinity (Huber and Sloan, 2001; Otto-Bliesner et al., 2002). Moreover, stable $\mathrm{Nd}$ isotopic composition in Eocene-Oligocene sediments from Site U1356 is consistent with modern-day formation of bottom water from Adélie Land, as reported by Huck et al. (2017).

Our evidence above points to the deposition of F1 during glacial cycles under poorly ventilated, low-oxygenation 
Paleoceanographic configuration of Wilkes Land region during the late warm Oligocene ( 26-25 Ma)

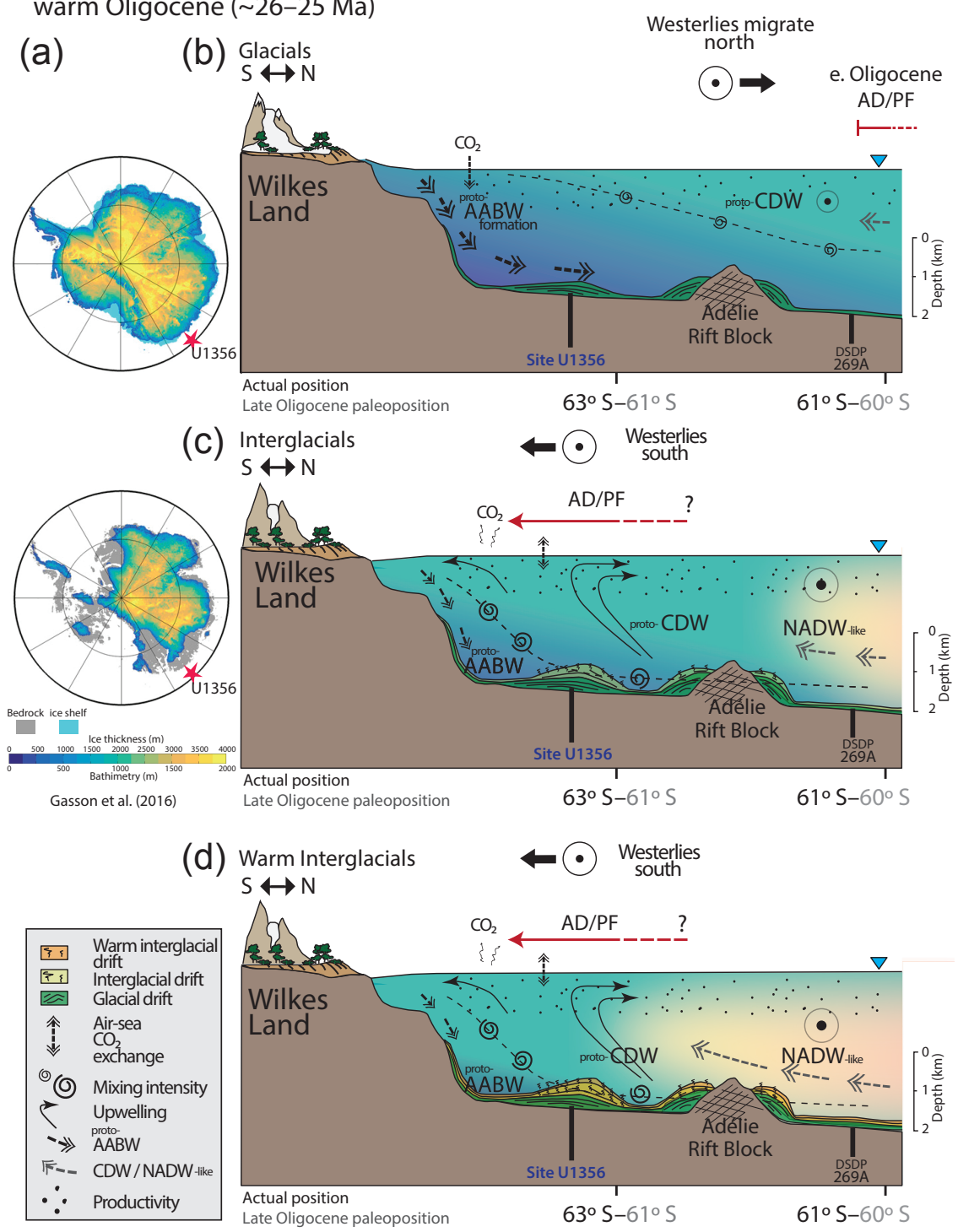

Figure 7. Paleoceanographic reconstructions based on our interpretations for Facies 1 and 2. (a) Modeled ice thickness for the mid-Miocene ice sheet by Gasson et al. (2016). (b) Glacial periods with low-obliquity configuration. Westerlies and polar front (PF) move northwards. There is enhanced proto-AABW formation. Low-ventilation conditions occur at the ocean-sediment interface, and mixing of waters masses is diminished. Bottom currents are weak and fluctuating, producing laminated sediments. (b) Interglacials occur during high-obliquity configuration. Westerlies and the PF move southwards, close to the Site U1356. Proto-AABW formation is reduced. Intrusions of protoCDW/NADW-like water mass reach southernmost positions. (c) During warm interglacials, NADW-like is enhanced and CaCO3 sedimentation is more abundant. (b, c) Bottom water ventilation and upwelling are more vigorous, with stronger bottom currents that result in fully bioturbated and silt-sized sediments.

conditions at the water-sediment interface (Fig. 7a). We postulate that during glacial periods, westerly winds and surface oceanic fronts migrate towards the equator, generating a more stratified ocean and reduced upwelling closer to the margin, with sporadic and fluctuating currents (Fig. 7a). Records of the Last Glacial Maximum show that this northward migration results in a weakening of the upwelling of the Circumpolar Deep Water (CDW; Govin et al., 2009), in- creasing stratification, and reduced mixing of water masses, also due to an enhanced sea ice formation; this was not seen during the late Oligocene. 


\subsubsection{Interglacial paleoceanographic configurations}

We differentiate between two interglacial paleoceanographic configurations based on the presence of some intervals of micritic limestone with calcareous nannofossils.

In general, the higher degree of bioturbation in F2 with no primary structures preserved and the ichnofacies association (i.e., Planolites and Zoophycos) suggest a more oxygenated environment in comparison with $\mathrm{F} 1$. This is supported by the covariance of $\mathrm{Mn}$ and $\mathrm{CaCO}_{3}$ est. (Fig. 4) where Mn enrichments can be interpreted as redox change variations (Calvert and Pedersen, 2007; Jaccard et al., 2016). More oxygenated conditions during interglacial periods can be achieved under more ventilated and mixed water masses, with enhanced current velocities. Enhanced currents during the deposition of F2 are interpreted as such based on coarser grain size and the increased accumulation of heavy and ferromagnetic minerals as indicated by the high values of the $\mathrm{Zr} / \mathrm{Ti}$ ratio and MS within F2 (Figs. 2, 4). The bigradational pattern of the $\mathrm{Zr} / \mathrm{Ba}$ and the MS (Fig. 4) is also interpreted as recording an increase followed by a decrease in current velocities within F2.

The intervals of micritic limestone within F2 have preserved calcareous nannofossils (Fig. 3d). The productivity of calcareous nannofossils and the later preservation of these coccoliths in the sediment indicate specific geochemical conditions enabling carbonate deposition and preservation. Although today nannoplankton is abundant in surface waters at the Antarctic Divergence (Eynaud et al., 1999), this rarely deposits on the deep ocean floor because of corrosive bottom waters, which dissolve calcareous rain. A number of studies in other areas of the Antarctic margin and the Southern Ocean have correlated the presence of calcareous nannofossils with the presence of temperate north component water masses (North Atlantic Deep Water-like, NADW) that intrude close to the Antarctic continent and influence the Southern Ocean during the late Oligocene (e.g., Nelson and Cooke, 2001; Pekar et al., 2006; Villa and Persico, 2006; Scher and Martin, 2008), the Miocene (DeCesare et al., 2013; Sangiorgi et al., 2018), and during more recent times such as the Quaternary (Diekman, 2007; Kemp et al., 2010; Villa et al., 2012).

The more oxygenated and ventilated conditions in our records suggest enhanced mixing of the water masses (Fig. 7b, c). We postulate that during interglacials westerly winds and the polar front are shifted south and become more aligned. Under these conditions, the upwelling of deep waters is likely promoted, facilitating the mixing and oxygenation of surface waters that form the precursor to bottom water. A similar process has been reported for the Holocene by Peck et al. (2015). Such a process would also generate increased geostrophic current velocities of the bottom water mass, supported by the coarser grain size and heavy mineral concentrations in the bioturbated F2 facies.
Similar to what occurs under the present warming, bottom water formation during interglacials is likely fresher and less dense due to enhanced freshwater runoff from surface and subglacial melt of the continental ice sheet (van Wijk and Rintoul, 2014). Today, a reduction in the volume of the AABW is compensated for by the expansion of the CDW (van Wijk and Rintoul, 2014), which forms by the mixing of abyssal, deep, and intermediate water masses, including the AABW and the NADW (Johnson, 2008). We hypothesize that during warmer interglacials, the influence of more northern-sourced water masses into the proto-CDW, relative to Antarctic-sourced water (Fig. 7c), could enable carbonate productivity and the preservation of coccolithophores remains, seen on at least 13 occasions in our record. These data are also in agreement with the $\delta^{13} \mathrm{C}$ global isotope oscillations between 26 and $25 \mathrm{Ma}$ (Cramer et al., 2009; Liebrand et al., 2017) that suggest low values for an AABW and high $\delta^{13} \mathrm{C}$ values for a NADW that may represent the different oceanic primary production and ventilation rates, as proposed in this work. In addition, $\delta^{13} \mathrm{C}$ records in the Atlantic show systematic offsets to lower values toward a North Atlantic signal for most of the late Oligocene to early Miocene. These data suggest the influence of two distinct deep-water sources: cooler southern component water and warmer northern component water (Billups et al., 2002; Pekar et al., 2006; Liebrand et al., 2011). In addition, the increased presence of North Component Deep Waters influencing this sector of the eastern Wilkes Land margin could be related to a slowdown of the southern limb of the overturning circulation.

\subsection{Orbital forcing and glacial and interglacial cyclicity}

The first spectral analysis on late Oligocene sediments from the eastern Wilkes Land margin at Site U1356 shows that glacial-interglacial cycles, resulting in changes in the oceanic configuration off Wilkes Land, are paced with variations in Earth's orbit and seasonal insolation. Although the data are somewhat discontinuous due to gaps in our record, they clearly show that the glacial-interglacial cyclicity (every $2 \mathrm{~m}$ or $41 \mathrm{kyr}$ ) discussed above has a persistent obliquity pacing throughout the late Oligocene interval studied (26-25 Ma) in the Wilkes Land. Consequently, this obliquitypaced cyclicity modulates the amount of deep-water production in the Southern Ocean and exerts a major control on oceanic configuration and current strength. Bottom current velocity fluctuations and ventilation of bottom sediments respond to the forcings applied by the strength of the Southern Hemisphere westerlies, by the position of the polar front $(\mathrm{PF})$ in respect of the site, and consequently by the water mass occupying the bottom of the basin at each time. In addition to obliquity, precession is also present, which implies a dynamic response of the EAIS and offshore oceanic water masses to orbital forcing.

East Antarctic ice volume fluctuations at orbital periodicities in the obliquity band in the Wilkes Land margin have 
been previously reported from early warm Pliocene (3-5 Ma) sediments obtained from Site U1361 (Patterson et al., 2014). In the Ross Sea, cyclicity in sediments collected by the CRP from the late Oligocene, the late Miocene, and the early warm Pliocene period was also paced by obliquity (Naish et al., 2001, 2009; McKay et al., 2009). Similar orbital variability in the deep-water circulation patterns has also been inferred to have occurred with the growth of the EAIS during the middle Miocene between 15.5 to $12.5 \mathrm{Ma}$ (Hall et al., 2003). In addition, other studies have linked changes in Atlantic meridional overturning (Lisiecki et al., 2008; Scher et al., 2015) and Antarctic circumpolar ocean circulation (Toggweiler and Russell, 2008) to obliquity forcing. An interglacial mechanism has been proposed whereby the southward expansion of westerly winds and associated Ekman transport is compensated for by enhanced upwelling of warmer, $\mathrm{CO}_{2}$-rich CDW (Toggweiler et al., 2008), which also promotes atmospheric warming. In the equatorial $\mathrm{Pa}-$ cific, Pälike et al. (2006) also report strong obliquity in the benthic $\delta^{13} \mathrm{C}$ isotopic record between 26 and $25 \mathrm{Myr}$, implying that changes in the carbon cycle (pacing glacial /interglacial periods) are triggered in the high southern latitudes and transferred to the global deep-ocean through the bottom water masses.

\section{Conclusions}

Our study provides new insights regarding Antarctic ice sheet and paleoceanographic configurations that prevailed in the eastern Wilkes Land margin between 26 and $25 \mathrm{Ma}$. Sediments at IODP Site U1356 during this interval are characterized by the alternation between two main facies ( $\mathrm{F} 1$ and F2), which are dominated by reworking by bottom currents with varying intensities of glacial-interglacial gravity flows and hemipelagic deposits. Claystones with silty laminations (F1) are interpreted as representing fluctuating bottom current intensities during glacial periods. Massive bioturbated silty clays and micritic limestones with coccoliths (F2) are interpreted as interglacial deposits and record maximum velocities of bottom currents at this site. The lack of icebergrafted debris (IRD), the absence of sea ice, elevated sea surface temperatures throughout the studied interval, and reconstructions of cool to temperate vegetation suggest that reduced glaciers or ice caps occupied the topographic highs and lowlands of the now overdeepened Wilkes Subglacial Basin between 26 and $25 \mathrm{Ma}$ and that iceberg calving was only a background process during this time due to the lack of marine-terminating ice sheets.

Glacial sediments record poorly ventilated, lowoxygenation conditions at the water-sediment interface that we postulate result when westerly winds and surface oceanic fronts migrate towards the equator and overturning is reduced near the Antarctic margin. During interglacial times, more oxygenated and better-ventilated conditions are inferred to have prevailed, which would act to enhance the mixing of the water masses with increased current velocities. We postulate that during interglacials, westerly winds shifted south and became more aligned with the Antarctic Divergence and polar fronts, which promoted the upwelling of deep waters and facilitated the mixing and oxygenation of bottom waters. Micritic limestone intervals within interglacial F2 record warmer paleoclimatic conditions when the influence of more northern-sourced water masses into the proto-CDW, relative to Antarctic-sourced water (Fig. 7c), could enable carbonate productivity and the preservation of coccolithophores remains. The preservation of carbonate in some F2 intervals supports previous paleoceanographic studies that consider at least a two-layer ocean with an Antarctic Bottom Water (undersaturated with respect to calcium carbonate) and a proto-Circumpolar Deep Water (CDW) with a greater influence of warmer Northern Component Deep Water mass (NADW-like) to reconcile intra-basinal differences in $\delta^{18} \mathrm{O}$ values (Pekar et al., 2006). Based on the number of carbonate-rich layers, warmer NADW-like waters reached the site at least 13 times during the studied interval.

Spectral analysis on late Oligocene sediments from the eastern Wilkes Land margin reveals that glacial-interglacial paleoceanographic changes during the late Oligocene are regulated primarily by obliquity, although frequencies in the eccentricity and precession band are also recorded. However, as we do not have a measure of ice dynamics during this time (e.g., iceberg-rafted debris), the orbital response of terrestrial ice in the Wilkes Land Basin remains ambiguous, beyond what is inferred from the deep-sea isotope record.

Code and data availability. The datasets to this article are available at PANGAEA (https://doi.pangaea.de/10.1594/PANGAEA. 892208, Salabarnada et al., 2018) and in the Supplement.

Supplement. The supplement related to this article is available online at: https://doi.org/10.5194/cp-14-991-2018-supplement.

Author contributions. $\mathrm{CE}$ and AS designed the research. PKB, $\mathrm{JH}, \mathrm{FS}$, and $\mathrm{HB}$ provided insights regarding biomarker-based sea surface temperatures and sea ice conditions based on dinocysts. UR provided XRF core-scanning data. FJJE and UR provided geochemical input. $\mathrm{CHN}$ and $\mathrm{RM}$ provided input with sedimentary and facies interpretations. MI provided the CT-scan data. JAF provided input in the paleoceanographic interpretations. DE and ALQ provided an Antarctic overview and petrographic input. SR and US provided palynology insights. AS and CE wrote the paper with input from all coauthors.

Competing interests. The authors declare that they have no conflict of interest. 
Acknowledgements. This research used samples and data provided by the Integrated Ocean Drilling Program, now the International Ocean Discovery Program (IODP). We thank the staff onboard IODP Exp. 318 and at the Gulf Coast, the Bremen, and the Kochi IODP core repositories for assistance in core handling and shipping. We thank Vera Lukies (MARUM) for technical support with XRF core scanning and Shizu Yanagimoto (KOCHI) for technical support with CT scans. We also thank the constructive comments of an anonymous reviewer and Steven Pekar that have helped to improve this paper. Funding for this research is provided by the Spanish Ministerio de Economía y Competitividad (grants CTM 2011-24079 and CTM2014-60451-C2-1-P), co-funded by the European Union through FEDER funds. Ulrich Salzmann thanks the Deutsche Forschungsgemeinschaft (DFG) (RO 1113/6). Peter K. Bijl, Francesca Sangiorgi, and Julian D. Hartman acknowledge funding through the NWO polar programme grant no 866.10.110. Peter K. Bijl acknowledges funding through NWO-VENI grant no 863.13.002. Ulrich Salzmann acknowledges funding received from the Natural Environment Research Council (NERC grant NE/H000984/1).

Edited by: David Thornalley

Reviewed by: Stephen Pekar and one anonymous referee

\section{References}

Abrahamsen, E. P., Meredith, M. P., Falkner, K. K., Torres-Valdes, S., Leng, M. J., Alkire, M. B., Bacon, S., Laxon, S. W., Polyakov, I., and Ivanov, V.: Tracer-derived freshwater composition of the Siberian continental shelf and slope following the extreme Arctic summer of 2007, Geophys. Res. Lett., 36, p. 5, https://doi.org/10.1029/2009GL037341, 2009.

Agnihotri, R., Altabet, M. A., Herbert, T. D., and Tierney, J. E.: Subdecadally resolved paleoceanography of the Peru margin during the last two millennia, Geochem. Geophy. Geosy., 9, 15, https://doi.org/10.1029/2007GC001744, 2008.

Anderson, J.: Antarctic marine geology, Cambridge University Press, Cambridge UK, 1999.

Anderson, J., Kurtz, D., and Weaver, F.: Sedimentation on the Antarctic continental slope, SEPM Spec. P., 27, 265-283, 1979.

Arndt, J. E., Schenke, H. W., Jakobsson, M., Nitsche, F. O., Buys, G., Goleby, B., Rebesco, M., Bohoyo, F., Hong, J., Black, J., Greku, R., Udintsev, G., Barrios, F., Reynoso-Peralta, W., Taisei, M., and Wigley, R.: The International Bathymetric Chart of the Southern Ocean (IBCSO) Version 1.0-A new bathymetric compilation covering circum-Antarctic waters, Geophys. Res. Lett., 40, 3111-3117, https://doi.org/10.1002/grl.50413, 2013.

Askin, R. A. and Raine, J. I.: Oligocene and Early Miocene Terrestrial Palynology of the Cape Roberts Drillhole CRP-2/2A, Victoria Land Basin, Antarctica, Terra Antarct., 7, 493-501, 2000.

Bahr, A., Jiménez-Espejo, F. J., Kolasinac, N., Grunert, P., Hernández-Molina, F. J., Röhl, U., Voelker, A. H. L., Escutia, C., Stow, D. A. V., Hodell, D., and Alvarez-Zarikian, C. A.: Deciphering bottom current velocity and paleoclimate signals from contourite deposits in the Gulf of Cádiz during the last $140 \mathrm{kyr}$ : An inorganic geochemical approach, Geochem. Geophy. Geosy., 15, 3145-3160, https://doi.org/10.1002/2014GC005356, 2014.

Barrett, P. J.: Cenozoic Climate and Sea Level History from Glacimarine Strata off the Victoria Land Coast, Cape Roberts
Project, Antarctica, in: Glacial Sedimentary Processes and Products, edited by: Hambrey, M. J., Christoffersen, P., Glasser, N., and Hubbard, B., 259-287, Blackwell Publishing, Oxford, 2007.

Bart, P. and De Santis, L.: Glacial Intensification During the Neogene: A Review of Seismic Stratigraphic Evidence from the Ross Sea, Antarctica, Continental Shelf, Oceanography 25, 166-183, https://doi.org/10.5670/oceanog.2012.92, 2012.

Bart, P. J. and Iwai, M.: The overdeepening hypothesis: How erosional modification of the marine-scape during the early Pliocene altered glacial dynamics on the Antarctic Peninsula's Pacific margin, Palaeogeogr. Palaeocl., 335-336, 42-51, https://doi.org/10.1016/j.palaeo.2011.06.010, 2012.

Beerling, D. J. and Royer, D. L.: Convergent Cenozoic $\mathrm{CO}_{2}$ history, Nat. Geosci., 4, 418-420, https://doi.org/10.1038/ngeo1186, 2011.

Bijl, P. K., Houben, A. J. P., Bruls, A., Pross, J., and Sangiorgi, F.: Stratigraphic calibration of Oligocene-Miocene organic-walled dinoflagellate cysts from offshore Wilkes Land, East Antarctica, and a zonation proposal, J. Micropalaeontol., 37, 105-138, https://doi.org/10.5194/jm-37-105-2018, 2018a.

Bijl, P. K., Houben, A. J. P., Hartman, J. D., Pross, J., Salabarnada, A., Escutia, C., and Sangiorgi, F.: Oligocene-Miocene paleoceanography off the Wilkes Land Margin (East Antarctica) based on organic-walled dinoflagellate cysts, Clim. Past Discuss., https://doi.org/10.5194/cp-2017-148, in review, 2018b.

Billups, K. and Schrag, D. P.: Application of benthic foraminiferal $\mathrm{Mg} / \mathrm{Ca}$ ratios to questions of Cenozoic climate change, Earth Planet. Sc. Lett., 209, 181-195, https://doi.org/10.1016/S0012821X(03)00067-0, 2003.

Billups, K., Channell, J. E. T., and Zachos, J.: Late Oligocene to early Miocene geochronology and paleoceanography from the subantarctic South Atlantic, Paleoceanography, 17, 4-1-4-11, https://doi.org/10.1029/2000PA000568, 2002.

Bindoff, N. L., Rosenberg, M. A., and Warner, M. J.: On the circulation and water masses over the Antarctic continental slope and rise between 80 and $150^{\circ}$ E, Deep-Sea Res. Pt. II, 47, 2299 2326, https://doi.org/10.1016/S0967-0645(00)00038-2, 2000.

Bohaty, S. M. and Harwood, D. M.: Southern Ocean pliocene paleotemperature variation from high-resolution silicoflagellate biostratigraphy, Mar. Micropaleontol., 33, 241-272, https://doi.org/10.1016/S0377-8398(97)00037-6, 1998.

Brancolini, G., Cooper, A. K., and Coren, F.: Seismic Facies and Glacial History in the Western Ross Sea (Antarctica), Geol. Seism. Stratigr. Antarct., Margin, AGU Antarct. Res. Ser., 68, 209-233, 1995.

Bromley, R. G. and Ekdale, A. A.: Chondrites: a trace fossil indicator of anoxia in sediments, Science, 80, 872-875, 1984.

Busetti, M., Caburlotto, A., Armand, L., Damiani, D., Giorgetti, G., Lucchi, R. G., Quilty, P. G., and Villa, G.: PlioQuaternary sedimentation on the Wilkes land continental rise: preliminary results, Deep-Sea Res. Pt. II, 50, 1529-1562, https://doi.org/10.1016/S0967-0645(03)00078-X, 2003.

Calvert, S. E. and Pedersen, T. F.: Sedimentary geochemistry of manganese; implications for the environment of formation of manganiferous black shales, Econ. Geol., 91, 36-47, https://doi.org/10.2113/gsecongeo.91.1.36, 1996.

Calvert, S. E. and Pedersen, T. F.: Chapter Fourteen Elemental Proxies for Palaeoclimatic and Palaeoceanographic Variability in 
Marine Sediments: Interpretation and Application, in: Developments in Marine Geology, 1, 567-644, 2007.

Campagne, P., Crosta, X., Houssais, M. N., Swingedouw, D., Schmidt, S., Martin, A., Devred, E., Capo, S., Marieu, V., Closset, I., and Massé, G.: Glacial ice and atmospheric forcing on the Mertz Glacier Polynya over the past 250 years, Nat. Commun., 6, 6642, https://doi.org/10.1038/ncomms7642, 2015.

Cook, C. P., van de Flierdt, T., Williams, T., Hemming, S. R., Iwai, M., Kobayashi, M., Jimenez-Espejo, F. J., Escutia, C., González, J. J., Khim, B.-K., McKay, R. M., Passchier, S., Bohaty, S. M., Riesselman, C. R., Tauxe, L., Sugisaki, S., Galindo, A. L., Patterson, M. O., Sangiorgi, F., Pierce, E. L., Brinkhuis, H., Klaus, A., Fehr, A., Bendle, J. A. P., Bijl, P. K., Carr, S. A., Dunbar, R. B., Flores, J. A., Hayden, T. G., Katsuki, K., Kong, G. S., Nakai, M., Olney, M. P., Pekar, S. F., Pross, J., Röhl, U., Sakai, T., Shrivastava, P. K., Stickley, C. E., Tuo, S., Welsh, K., and Yamane, M.: Dynamic behaviour of the East Antarctic ice sheet during Pliocene warmth, Nat. Geosci. 6, 765-769, https://doi.org/10.1038/ngeo1889, 2013.

Cook, C. P., Hill, D. J., van de Flierdt, T., Williams, T., Hemming, S. R., Dolan, A. M., Pierce, E. L., Escutia, C., Harwood, D., Cortese, G., and Gonzales, J. J.: Sea surface temperature control on the distribution of far-traveled Southern Ocean ice-rafted detritus during the Pliocene, Paleoceanography, 29, 533-548, https://doi.org/10.1002/2014PA002625, 2014.

Cook, C. P., Hemming, S. R., van de Flierdt, T., Pierce Davis, E. L., Williams, T., Galindo, A. L., Jiménez-Espejo, F. J., and Escutia, C.: Glacial erosion of East Antarctica in the Pliocene: A comparative study of multiple marine sediment provenance tracers, Chem. Geol., 466, 199-218, https://doi.org/10.1016/j.chemgeo.2017.06.011, 2017.

Coxall, H. K., Wilson, P. A., Pälike, H., Lear, C. H., and Backman, J.: Rapid stepwise onset of Antarctic glaciation and deeper calcite compensation in the Pacific Ocean, Nature, 433, 53-57, https://doi.org/10.1038/nature03135, 2005.

Cramer, B. S., Toggweiler, J. R., Wright, J. D., Katz, M. E., and Miller, K. G.: Ocean overturning since the Late Cretaceous: Inferences from a new benthic foraminiferal isotope compilation, Paleoceanography, 24, 14, https://doi.org/10.1029/2008PA001683, 2009.

Croudace, I. W., Rindby, A., and Rothwell, R. G.: ITRAX: description and evaluation of a new multi-function X-ray core scanner, Geol. Soc. Spec. Publ., 267, 51-63, 2006.

Damiani, D., Giorgetti, G., and Turbanti, I. M.: Clay mineral fluctuations and surface textural analysis of quartz grains in PlioceneQuaternary marine sediments from Wilkes Land continental rise (East-Antarctica): Paleoenvironmental significance, Mar. Geol. 226, 281-295, https://doi.org/10.1016/j.margeo.2005.11.002, 2006.

DeCesare, M., Pekar, S. F., and DeCesare: Investigating a Middle to Late Miocene Carbonate Preservation Event in the Southern Ocean, Am. Geophys. Union, Fall Meet. 2013, Abstr. \#PP43A2072, 12-13, 2013.

DeConto, R. M. and Pollard, D.: Contribution of Antarctica to past and future sea-level rise, Nature, 531, 591-597, https://doi.org/10.1038/nature17145, 2016.

De Santis, L., Anderson, J. B., Brancolini, G. and Zayatz, I.: Seismic Record of Late Oligocene Through Miocene Glaciation on the Central and Eastern Continental Shelf of the Ross Sea, in Ge- ology and Seismic stratigraphy of the Antarctic margin, Antar. Res. S, 68, 235-260, 2013.

Diekmann, B.: Sedimentary patterns in the late Quaternary Southern Ocean, Deep-Sea Res. Pt. II, 54, 2350-2366, https://doi.org/10.1016/j.dsr2.2007.07.025, 2007.

Duliu, O. G.: Computer axial tomography in geosciences: An overview, Earth Sci. Rev, 48, 265-281, https://doi.org/10.1016/S0012-8252(99)00056-2, 1999.

Dypvik, H. and Harris, N. B.: Geochemical facies analysis of finegrained siliciclastics using $\mathrm{Th} / \mathrm{U}, \mathrm{Zr} / \mathrm{Rb}$ and $(\mathrm{Zr}+\mathrm{Rb}) / \mathrm{Sr}$ ratios, Chem. Geol., 181, 131-146, https://doi.org/10.1016/S00092541(01)00278-9, 2001.

Ehrmann, W., Setti, M., and Marinoni, L.: Clay minerals in Cenozoic sediments off Cape Roberts (McMurdo Sound, Antarctica) reveal palaeoclimatic history, Palaeogeogr. Palaeocl., 229, 187211, https://doi.org/10.1016/j.palaeo.2005.06.022, 2005.

Eittreim, S. L., Cooper, A. K., and Wannesson, J.: Seismic stratigraphic evidence of ice-sheet advances on the Wilkes Land margin of Antarctica, Sediment. Geol., 96, 131-156, https://doi.org/10.1016/0037-0738(94)00130-M, 1995.

Escutia, C. and Brinkhuis, H.: From Greenhouse to Icehouse at the Wilkes Land Antarctic Margin, in arth and Life Processes Discovered from Subseafloor Environments: A Decade of Science Achieved by the Integrated Ocean Drilling Program (IODP), vol. 7, edited by: Stein, R., Blackman, D. K., Inagaki, F., and Larsen, H.-C., 295-328, Elsevier, Amsterdam., 2014.

Escutia, C., Eittreim, S. L., Cooper, A. K., and Nelson, C. H.: Cenozoic sedimentation on the Wilkes Land continental rise, Antarctica, in: The Antarctic Region: Geological Evolution and Processes, Proc. Int. Symp. Antarct. Earth Sci., 7, 791-795, 1997.

Escutia, C., Eittreim, S. L., Cooper, A. K., and Nelson, C. H.: Morphology and acoustic character of the antarctic Wilkes Land turbidite systems: Ice-sheet-sourced versus river-sourced fans, J. Sediment. Res., 70, 84-93, https://doi.org/10.1306/2DC409000E47-11D7-8643000102C1865D, 2000.

Escutia, C., Nelson, C. H., Acton, G. D., Eittreim, S. L., Cooper, A. K., Warnke, D. A., and Jaramillo, J. M.: Current controlled deposition on the Wilkes Land continental rise, Antarctica, Geol. Soc. London, Mem., 22, 373-384, https://doi.org/10.1144/GSL.MEM.2002.022.01.26, 2002.

Escutia, C., Warnke, D., Acton, G., Barcena, A., Burckle, L., Canals, M., and Frazee, C.: Sediment distribution and sedimentary processes across the Antarctic Wilkes Land margin during the Quaternary, Deep-Sea Res. Pt. II, 50, 1481-1508, https://doi.org/10.1016/S0967-0645(03)00073-0, 2003.

Escutia, C., De Santis, L., Donda, F., Dunbar, R.B., Cooper, A. K., Brancolini, G., and Eittreim, S. L.: Cenozoic ice sheet history from East Antarctic Wilkes Land continental margin sediments, Glob. Planet. Change, 45, 51-81, https://doi.org/10.1016/j.gloplacha.2004.09.010, 2005.

Escutia, C., Bárcena, M. A., Lucchi, R. G., Romero, O., Ballegeer, A. M., Gonzalez, J. J., and Harwood, D. M.: Circum-Antarctic warming events between 4 and $3.5 \mathrm{Ma}$ recorded in marine sediments from the Prydz Bay (ODP Leg 188) and the Antarctic Peninsula (ODP Leg 178) margins, Glob. Planet. Change, 69, 170-184, https://doi.org/10.1016/j.gloplacha.2009.09.003, 2009.

Escutia, C., Brinkhuis, H., Klaus, A., and Scientists, I. E.: 318: Site U1356, in: Proceeding of the Integrated Ocean Drilling Program, 
318, Integrated Ocean Drilling Program Management International, Inc., Tokyo, 2011.

Eynaud, F., Giraudeau, J., Pichon, J. J., and Pudsey, C. J.: Seasurface distribution of coccolithophores, diatoms, silicoflagellates and dinoflagellates in the South Atlantic Ocean during the late austral summer 1995, Deep. Res. Part I Oceanogr. Res. Pap., 46, 451-482, https://doi.org/10.1016/S0967-0637(98)00079-X, 1999.

Field, C. B., Barros, V. R., Dokken, D. J., Mach, K. J., Mastrandrea, M. D., Bilir, T. E., Chatterjee, M., Ebi, K. L., Estrada, Y. O., and Genova, R. C.: IPCC, 2014: Climate Change 2014: Impacts, Adaptation, and Vulnerability, Part A: Global and Sectoral Aspects, Contribution of Working Group II to the Fifth Assessment Report of the Intergovernmental Panel on Climate Change, edited by: Field, C. B., Barros, V. R., Dokken, D. J., Mach, K. J., Mastrandrea, M. D., Bilir, T. E., Chatterjee, M., Ebi, K. L., Estrada, Y. O., Genova, R. C., Girma, B., Kissel, E. S., Levy, A. N., MacCracken, S., Mastrandrea, P. R., and White, L. L., Cambridge University Press, Cambridge, United Kingdom and New York, NY, USA, available at: http://hdl.handle.net/20.500.11822/17771 (last access: July 2018), 2014.

Florindo, F., Roberts, A. P., and Palmer, M. R.: Magnetite dissolution in siliceous sediments, Geochem. Geophy. Geosy., 4, 1-13, https://doi.org/10.1029/2003GC000516, 2003.

Foster, G. L. and Rohling, E. J.: Relationship between sea level and climate forcing by $\mathrm{CO}_{2}$ on geological timescales, Proc. Natl. Acad. Sci. USA, 110, 1209-14, https://doi.org/10.1073/pnas.1216073110, 2013.

Foubert, A. and Henriet, J.-P.: Nature and significance of the recent carbonate mound record: the Mound Challenger code, Springer, Berlin, Heidelberg, 2009.

Fouinat, L., Sabatier, P., Poulenard, J., Reyss, J.-L., Montet, X., and Arnaud, F.: A new CT scan methodology to characterize a small aggregation gravel clast contained in a soft sediment matrix, Earth Surf. Dynam., 5, 199-209, https://doi.org/10.5194/esurf5-199-2017, 2017.

Fretwell, P., Pritchard, H. D., Vaughan, D. G., Bamber, J. L., Barrand, N. E., Bell, R., Bianchi, C., Bingham, R. G., Blankenship, D. D., Casassa, G., Catania, G., Callens, D., Conway, H., Cook, A. J., Corr, H. F. J., Damaske, D., Damm, V., Ferraccioli, F., Forsberg, R., Fujita, S., Gim, Y., Gogineni, P., Griggs, J. A., Hindmarsh, R. C. A., Holmlund, P., Holt, J. W., Jacobel, R. W., Jenkins, A., Jokat, W., Jordan, T., King, E. C., Kohler, J., Krabill, W., Riger-Kusk, M., Langley, K. A., Leitchenkov, G., Leuschen, C., Luyendyk, B. P., Matsuoka, K., Mouginot, J., Nitsche, F. O., Nogi, Y., Nost, O. A., Popov, S. V., Rignot, E., Rippin, D. M., Rivera, A., Roberts, J., Ross, N., Siegert, M. J., Smith, A. M., Steinhage, D., Studinger, M., Sun, B., Tinto, B. K., Welch, B. C., Wilson, D., Young, D. A., Xiangbin, C., and Zirizzotti, A.: Bedmap2: improved ice bed, surface and thickness datasets for Antarctica, The Cryosphere, 7, 375-393, https://doi.org/10.5194/tc-7-375-2013, 2013.

Fukamachi, Y., Wakatsuchi, M., Taira, K., Kitagawa, S., Furukawa, T., and Fukuchi, M.: Seasonal variability of bottom water properties off Adlie Land, Antarctica, 105, 6531-6540, https://doi.org/10.1029/1999JC900292, 2000.

Fukamachi, Y., Rintoul, S. R., Church, J. A., Aoki, S., Sokolov, S., Rosenberg, M. A., and Wakatsuchi, M.: Strong export of Antarc- tic Bottom Water east of the Kerguelen plateau, Nat. Geosci., 3, 327-331, https://doi.org/10.1038/ngeo842, 2010.

Gasson, E., DeConto, R. M., Pollard, D., and Levy, R. H.: Dynamic Antarctic ice sheet during the early to midMiocene, Proc. Natl. Acad. Sci. USA, 113, 3459-3464, https://doi.org/10.1073/pnas.1516130113, 2016.

Gilbert, R., Nielsen, N., Desloges, J., and Rasch, M.: Contrasting glacimarine sedimentary environments of two arctic fiords on Disko, West Greenland, Mar. Geol., 147, 63-83, https://doi.org/10.1016/S0025-3227(98)00008-5, 1998.

Govin, A., Michel, E., Labeyrie, L., Waelbroeck, C., Dewilde, F., and Jansen, E.: Evidence for northward expansion of Antarctic Bottom Water mass in the Southern Ocean during the last glacial inception, Paleoceanography, 24, https://doi.org/10.1029/2008PA001603, 2009.

Grobe, H. and Mackensen, A.: Late Quaternary climatic cycles as recorded in sediments from the Antarctic Continental margin, Antarct. Paleoenviroments A Perspect. Glob. Chang. Antarct. Res. Ser., 56, 349-376, https://doi.org/10013/epic.11662.d001, 1992.

Hall, I. R., McCave, I. N., Zahn, R., Carter, L., Knutz, P. C., and Weedon, G. P.: Paleocurrent reconstruction of the deep Pacific inflow during the middle Miocene: Reflections of East Antarctic Ice Sheet growth, Paleoceanography, 18, https://doi.org/10.1029/2002PA000817, 2003.

Hannah, M. J., Wilson, G. J., and Wrenn, J. H.: Oligocene and miocene marine palynomorphs from CRP-2/2A, Victoria Land Basin, Antarctica, Terra Antarct., 7, 503-511, 2000.

Hannah, M. J., Wrenn, J., and Wilson, G.: Preliminary report on early Oligocene and latest Eocene marine palynomorphs from CRP-3 drillhole, Victoria Land Basin, Antarctica, Terra Antart., 8, 383-388, 2001.

Hartman, J. D., Sangiorgi, F., Salabarnada, A., Peterse, F., Houben, A. J. P., Schouten, S., Escutia, C., and Bijl, P. $\mathrm{K}$.: Oligocene $\mathrm{TEX}_{86}$-derived seawater temperatures from offshore Wilkes Land (East Antarctica), Clim. Past Discuss., https://doi.org/10.5194/cp-2017-153, in review, 2018.

Hauptvogel, D. W.: The State Of The Oligocene Icehouse World: Sedimentology, Provenance, And Stable Isotopes Of Marine Sediments From The Antarctic Continental Margin, PhD Dissertation, University Of New York, 2015.

Hauptvogel, D. W., Pekar, S. F., and Pincay, V.: Evidence for a heavily glaciated Antarctica during the late Oligocene warming (27.8-24.5 Ma): Stable isotope records from ODP Site 690, Paleoceanography, 32, 384-396, https://doi.org/10.1002/2016PA002972, 2017.

Hayes, D. E. and Frakes, L. A.: General Synthesis, Deep Sea Drilling Project Leg 28, in Initial Reports of the Deep Sea Drilling Project, US, 28, 19-48, 1975.

Hennekam, R. and de Lange, G.: X-ray fluorescence core scanning of wet marine sediments: methods to improve quality and reproducibility of high-resolution paleoenvironmental records, Limnol. Oceanogr. Methods, 10, 991-1003, https://doi.org/10.4319/lom.2012.10.991, 2012.

Hepp, D. A.: Late Miocene-Pliocene glacial cyclicity in a deepsea sediment drift on the Antarctic Peninsula continental margin: Sedimentary and diagenetic processes, PhD Thesis, Bremen, Universität, Bremen, 2007. 
Hepp, D. A., Mörz, T., Hensen, C., Frederichs, T., Kasten, S., Riedinger, N., and Hay, W. W.: A late Miocene - early Pliocene Antarctic deepwater record of repeated iron reduction events, Mar. Geol., 266, 198-211, https://doi.org/10.1016/j.margeo.2009.08.006, 2009.

Hodell, D. A., Channell, J. E. T., Curtis, J. H., Romero, O. E., and Röhl, U.: Onset of "Hudson Strait" Heinrich events in the eastern North Atlantic at the end of the middle Pleistocene transition ( $\sim 640 \mathrm{ka})$, Paleoceanography, 23 , https://doi.org/10.1029/2008PA001591, 2008.

Houben, A. J. P., Bijl, P. K., Pross, J., Bohaty, S. M., Passchier, S., Stickley, C. E., Rohl, U., Sugisaki, S., Tauxe, L., van de Flierdt, T., Olney, M., Sangiorgi, F., Sluijs, A., Escutia, C., and Brinkhuis, H.: Reorganization of Southern Ocean Plankton Ecosystem at the Onset of Antarctic Glaciation, Science, 340, 341-344, https://doi.org/10.1126/science.1223646, 2013.

Huber, M. and Sloan, L. C.: Heat transport, deep waters, and thermal gradients: Coupled simulation of an Eocene greenhouse climate, Geophys. Res. Lett., 28, 3481-3484, https://doi.org/10.1029/2001GL012943, 2001.

Huck, C. E., van de Flierdt, T., Bohaty, S. M., and Hammond, S. J.: Antarctic climate, Southern Ocean circulation patterns, and deep water formation during the Eocene, Paleoceanography, 32, 674-691, https://doi.org/10.1002/2017PA003135, 2017.

Jaccard, S. L., Galbraith, E. D., Martínez-García, A., and Anderson, R. F.: Covariation of deep Southern Ocean oxygenation and atmospheric $\mathrm{CO}_{2}$ through the last ice age, Nature, 530, 207-10, https://doi.org/10.1038/nature16514, 2016.

Johnson, G. C.: Quantifying Antarctic Bottom Water and North Atlantic Deep Water volumes, J. Geophys. Res.-Ocean., 113, 1-13, https://doi.org/10.1029/2007JC004477, 2008.

Kemp, E. M. and Barrett, P. J.: Antarctic glaciation and early Tertiary vegetation, Nature, 258, 507-508, https://doi.org/10.1038/258507a0, 1975.

Kemp, E. M., Grigorov, I., Pearce, R. B., and Naveira Garabato, A. C.: Migration of the Antarctic Polar Front through the mid-Pleistocene transition: evidence and climatic implications, Quaternary Sci. Rev., 29, 1993-2009, https://doi.org/10.1016/j.quascirev.2010.04.027, 2010.

Kominz, M. A. and Pekar, S. F.: Oligocene eustasy from two-dimensional sequence stratigraphic backstripping, Geol. Soc. Am. Bull., 113, 291-304, https://doi.org/10.1130/00167606(2001)113<0291:OEFTDS>2.0.CO;2, 2001.

Korff, L., von Dobeneck, T., Frederichs, T., Kasten, S., Kuhn, G., Gersonde, R., and Diekmann, B.: Cyclic magnetite dissolution in Pleistocene sediments of the abyssal northwest Pacific Ocean: Evidence for glacial oxygen depletion and carbon trapping, Paleoceanography, 31, 600-624, https://doi.org/10.1002/2015PA002882, 2016.

Kuhn, G. and Diekmann, B.: Late Quaternary variability of ocean circulation in the southeastern South Atlantic inferred from the terrigenous sediment record of a drift deposit in the southern Cape Basin (ODP Site 1089), Palaeogeogr. Palaeocl., 182, 287303, https://doi.org/10.1016/S0031-0182(01)00500-4, 2002.

Laskar, J., Robutel, P., Joutel, F., Gastineau, M., Correia, A. C. M., and Levrard, B.: A long-term numerical solution for the insolation quantities of the Earth, Astron. Astrophys., 428, 261-285, https://doi.org/10.1051/0004-6361:20041335, 2004.
Lear, C. H., Rosenthal, Y., Coxall, H. K., and Wilson, P. A.: Late Eocene to early Miocene ice sheet dynamics and the global carbon cycle, Paleoceanography, 19, https://doi.org/10.1029/2004PA001039, 2004.

Leckie, R. and Webb, P.: Late Oligocene - early Miocene glacial record of the Ross Sea, Antarctica: Evidence from DSDP site 270, Geology, 11, 578, https://doi.org/10.1130/00917613(1983)11<578:LOMGRO>2.0.CO;2, 1983.

Levy, R., Harwood, D., Florindo, F., Sangiorgi, F., Tripati, R., von Eynatten, H., Gasson, E., Kuhn, G., Tripati, A., DeConto, R., Fielding, C., Field, B., Golledge, N., McKay, R., Naish, T., Olney, M., Pollard, D., Schouten, S., Talarico, F., Warny, S., Willmott, V., Acton, G., Panter, K., Paulsen, T., and Taviani, M.: Antarctic ice sheet sensitivity to atmospheric $\mathrm{CO}_{2}$ variations in the early to mid-Miocene, Proc. Natl. Acad. Sci. USA, , 113 , 3453-3458, https://doi.org/10.1073/pnas.1516030113, 2016.

Liebrand, D., Lourens, L. J., Hodell, D. A., de Boer, B., van de Wal, R. S. W., and Pälike, H.: Antarctic ice sheet and oceanographic response to eccentricity forcing during the early Miocene, Clim. Past, 7, 869-880, https://doi.org/10.5194/cp-7-869-2011, 2011.

Liebrand, D., Beddow, H. M., Lourens, L. J., Pälike, H., Raffi, I., Bohaty, S. M., Hilgen, F. J., Saes, M. J. M., Wilson, P. A., van Dijk, A. E., Hodell, D. A., Kroon, D., Huck, C. E., and Batenburg, S. J.: Cyclostratigraphy and eccentricity tuning of the early Oligocene through early Miocene (30.1-17.1 Ma): Cibicides mundulus stable oxygen and carbon isotope records from Walvis Ridge Site 1264, Earth Planet. Sc. Lett., 450, 392-405, https://doi.org/10.1016/j.epsl.2016.06.007, 2016.

Liebrand, D., de Bakker, A. T. M., Beddow, H. M., Wilson, P. A., Bohaty, S. M., Ruessink, G., Pälike, H., Batenburg, S. J., Hilgen, F. J., Hodell, D. A., Huck, C. E., Kroon, D., Raffi, I., Saes, M. J. M., van Dijk, A. E., and Lourens, L. J.: Evolution of the early Antarctic ice ages, Proc. Natl. Acad. Sci. USA, 114, 3867-3872, https://doi.org/10.1073/pnas.1615440114, 2017.

Lisiecki, L. E., Raymo, M. E., and Curry, W. B.: Atlantic overturning responses to Late Pleistocene climate forcings, Nature, 456, 85-88, https://doi.org/10.1038/nature07425, 2008.

Lucchi, R. G. and Rebesco, M.: Glacial contourites on the Antarctic Peninsula margin: insight for palaeoenvironmental and palaeoclimatic conditions, Geol. Soc. Spec. Publ., 276, 111-127, https://doi.org/10.1144/GSL.SP.2007.276.01.06, 2007.

Mackensen, A., Grobe, H., Hubberten, H., and Spiess, V.: Stable isotope stratigraphy from the Antarctic continental margin during the last one million years, Mar. Geol., 87, 315-321, https://doi.org/10.1016/0025-3227(89)90068-6, 1989.

Mann, M. E. and Lees, J. M.: Robust estimation of background noise and signal detection in climatic time series, Climate Change, 33, 409-445, https://doi.org/10.1007/BF00142586, 1996.

Martín-Chivelet, J., Fregenal-Martínez, M. A., and Chacón, B.: Traction Structures in Contourites, in: Contourites, chap. 10, 157-182, 2008.

McKay, R., Browne, G., Carter, L., Cowan, E., Dunbar, G., Krissek, L., Naish, T., Powell, R., Reed, J., Talarico, F., and Wilch, T.: The stratigraphic signature of the late Cenozoic Antarctic Ice Sheets in the Ross Embayment, Geol. Soc. Am. Bull., 121, 1537-1561, https://doi.org/10.1130/B26540.1, 2009.

McKay, R., Naish, T., Carter, L., Riesselman, C., Dunbar, R., Sjunneskog, C., Winter, D., Sangiorgi, F., Warren, C., Pagani, M., 
Schouten, S., Willmott, V., Levy, R., DeConto, R., and Powell, R. D.: Antarctic and Southern Ocean influences on Late Pliocene global cooling, Proc. Natl. Acad. Sci. USA, 109, 6423-6428, https://doi.org/10.1073/pnas.1112248109, 2012.

Meyers, S. R.: Astrochron: An R Package for Astrochronology, available at: http://cran.r-project.org/package=astrochron (last access: July 2018), 2014.

Meyers, S. R., Sageman, B. B., and Hinnov, L. A.: Integrated quantitative stratigraphy of the Cenomanian-Turonian Bridge Creek Limestone Member using evolutive harmonic analysis and stratigraphic modeling, J. Sediment. Res., 71, 628-644, 2001.

Meyers, S. R., Sageman, B. B., and Arthur, M. A.: Obliquity forcing of organic matter accumulation during Oceanic Anoxic Event 2, Paleoceanography, 27, https://doi.org/10.1029/2012PA002286, 2012.

Moore, W. S. and Dymond, J.: Fluxes of 226Ra and barium in the Pacific Ocean: The importance of boundary processes, Earth Planet. Sc. Lett., 107, 55-68, https://doi.org/10.1016/0012821X(91)90043-H, 1991.

Mudelsee, M., Bickert, T., Lear, C. H., and Lohmann, G.: Cenozoic climate changes: A review based on time series analysis of marine benthic $\delta^{18} \mathrm{O}$ records, Rev. Geophys. 52, 333-374, https://doi.org/10.1002/2013RG000440, 2014.

Naish, T., Powell, R., Levy, R., Wilson, G., Scherer, R., Talarico, F., Krissek, L., Niessen, F., Pompilio, M., Wilson, T., Carter, L., Deconto, R., Huybers, P., Mckay, R., Pollard, D., Ross, J., Winter, D., Barrett, P., Browne, G., Cody, R., Cowan, E., Crampton, J., Dunbar, G., Dunbar, N., Florindo, F., Gebhardt, C., Graham, I., Hannah, M., Hansaraj, D., Harwood, D., Helling, D., Henrys, S., Hinnov, L., Kuhn, G., Kyle, P., Läufer, A, Maffioli, P., Magens, D., Mandernack, K., McIntosh, W., Millan, C., Morin, R., Ohneiser, C., Paulsen, T., Persico, D., Raine, I., Reed, J., Riesselman, C., Sagnotti, L., Schmitt, D., Sjunneskog, C., Strong, P., Taviani, M., Vogel, S., Wilch, T., and Williams, T.: Obliquity-paced Pliocene West Antarctic ice sheet oscillations, Nature, 458, 322328, https://doi.org/10.1038/nature07867, 2009.

Naish, T. R., Woolfe, K. J., Barrett, P. J., Wilson, G. S., Atkins, C., Bohaty, S. M., Bäcker, C. J., Claps, M., Davey, F. J., Dunbar, G. B., Dunn, A. G., Fielding, C. R., Florindo, F., Hannah, M. J., Harwood, D. M., Henrys, S. A, Krissek, L. A, Lavelle, M., van der Meer, J., McIntosh, W. C., Niessen, F., Passchier, S., Powell, R. D., Roberts, A. P., Sagnotti, L., Scherer, R. P., Strong, C. P., Talarico, F., Verosub, K. L., Villa, G., Watkins, D. K., Webb, P.-N., and Wonik, T.: Orbitally induced oscillations in the East Antarctic ice sheet at the Oligocene/Miocene boundary, Nature 413, 719-723, https://doi.org/10.1038/35099534, 2001.

Nelson, C. S. and Cooke, P. J.: History of oceanic front development in the New Zealand sector of the Southern Ocean during the Cenozoic - a synthesis, New Zeal. J. Geol. Geophys., 44, 535553, https://doi.org/10.1080/00288306.2001.9514954, 2001.

O’Regan, M., John, K. St., Moran, K., Backman, J., King, J., Haley, B. A., Jakobsson, M., Frank, M., and Röhl, U.: Plio-Pleistocene trends in ice rafted debris on the Lomonosov Ridge, Quat. Int., 219, 168-176, https://doi.org/10.1016/j.quaint.2009.08.010, 2010.

Orsi, A. H., Whitworth, T., and Nowlin, W. D.: On the meridional extent and fronts of the Antarctic Circumpolar Current, Deep-Sea Res. Pt. I, 42, 641-673, https://doi.org/10.1016/09670637(95)00021-W, 1995.
Orsi, A. H., Johnson, G. C., and Bullister, J. L.: Circulation, mixing, and production of Antarctic Bottom Water, Prog. Oceanogr., 43, 55-109, https://doi.org/0.1016/S0079-6611(99)00004-X, 1999.

Otto-Bliesner, B. L., Brady, E. C., and Shields, C.: Late Cretaceous ocean: Coupled simulations with the National Center for Atmospheric Research Climate System Model, J. Geophys. Res., 107, ACL-11, https://doi.org/10.1029/2001JD000821, 2002.

Pagani, M., Zachos, J. C., Freeman, K. H., Tipple, B., and Bohaty, S.: Marked Decline in Atmospheric Carbon Dioxide Concentrations During the Paleogene, Science, 80, 600-603, https://doi.org/10.1126/science.1110063, 2005.

Pälike, H., Norris, R. D., Herrle, J. O., Wilson, P. A, Coxall, H. K., Lear, C. H., Shackleton, N. J., Tripati, A. K., and Wade, B. S.: The Heartbeat of the Oligocene Climate System, Science, 314, 1894-1898, https://doi.org/10.1126/science.1133822, 2006.

Patterson, M. O., McKay, R., Naish, T., Escutia, C., JimenezEspejo, F. J., Raymo, M. E., Meyers, S. R., Tauxe, L., Brinkhuis, H., Klaus, A., Fehr, A., Bendle, J. A. P., Bijl, P. K., Bohaty, S. M., Carr, S. A., Dunbar, R. B., Flores, J. A., Gonzalez, J. J., Hayden, T. G., Iwai, M., Katsuki, K., Kong, G. S., Nakai, M., Olney, M. P., Passchier, S., Pekar, S. F., Pross, J., Riesselman, C. R., Röhl, U., Sakai, T., Shrivastava, P. K., Stickley, C. E., Sugasaki, S., Tuo, S., van de Flierdt, T., Welsh, K., Williams, T., and Yamane, M.: Orbital forcing of the East Antarctic ice sheet during the Pliocene and Early Pleistocene, Nat. Geosci., 7, 841-847, https://doi.org/10.1038/ngeo2273, 2014.

Payne, R. R., Conolly, J. R. and Aabbott, W. H.: Turbidite Muds within Diatom Ooze off Antarctica: Pleistocene Sediment Variation Defined by Closely Spaced Piston Cores, GSA Bull., 83, 481-486, https://doi.org/10.1130/00167606(1972)83[481:TMWDOO]2.0.CO;2, 1972.

Peck, V. L., Allen, C. S., Kender, S., McClymont, E. L., and Hodgson, D. A.: Oceanographic variability on the West Antarctic Peninsula during the Holocene and the influence of upper circumpolar deep water, Quat. Sci. Rev., 119, 54-65, https://doi.org/10.1016/j.quascirev.2015.04.002, 2015.

Pekar, S. F., DeConto, R. M., and Harwood, D. M.: Resolving a late Oligocene conundrum: Deep-sea warming and Antarctic glaciation, Palaeogeogr. Palaeocl., 231, 29-40, 2006.

Pollard, D. and DeConto, R. M.: Modelling West Antarctic ice sheet growth and collapse through the past five million years, Nature, 458, 329-32, https://doi.org/10.1038/nature07809, 2009.

Prebble, J. G., Raine, J. I., Barrett, P. J., and Hannah, M. J.: Vegetation and climate from two Oligocene glacioeustatic sedimentary cycles ( 31 and $24 \mathrm{Ma}$ ) cored by the Cape Roberts Project, Victoria Land Basin, Antarctica, Palaeogeogr. Palaeocl., 231, 41-57, https://doi.org/10.1016/j.palaeo.2005.07.025, 2006.

Pritchard, H. D., Ligtenberg, S. R. M., Fricker, H. A., Vaughan, D. G., van den Broeke, M. R., and Padman, L.: Antarctic ice-sheet loss driven by basal melting of ice shelves, Nature, 484, 502-505, https://doi.org/10.1038/nature10968, 2012.

Pudsey, C. J.: Late Quaternary changes in Antarctic Bottom Water velocity inferred from sediment grain size in the northern Weddell Sea, Mar. Geol, 107, 9-33, https://doi.org/10.1016/00253227(92)90066-Q, 1992.

Pudsey, C. J.: Sedimentation on the continental rise west of the Antarctic Peninsula over the last three glacial cycles, Mar. Geol., 167, 313-338, https://doi.org/10.1016/S0025-3227(00)00039-6, 2000. 
Pudsey, C. J. and Camerlenghi, A.: Glacial - interglacial deposition on a sediment drift on the Pacific margin of the Antarctic Peninsula, Antarct. Sci., 10, 286-308, https://doi.org/10.1017/S0954102098000376, 1998.

Pudsey, C. J. and Howe, J. A.: Quaternary history of the Antarctic Circumpolar Current: evidence from the Scotia Sea, Mar. Geol., 148, 83-112, https://doi.org/10.1016/S0025-3227(98)00014-0, 1998.

Raine, J. and Askin, R.: Terrestrial palynology of Cape Roberts Project Drillhole CRP-3, Victoria Land Basin, Antarctica, Terra Antart., 8, 389-400, 2001.

Rebesco, M. and Camerlenghi, A. (Eds.): Contourites, Elsevier, 60, Oxford UK, 2008

Rebesco, M., Hernández-Molina, F. J., Van Rooij, D., and Wåhlin, A.: Contourites and associated sediments controlled by deep-water circulation processes: State-of-theart and future considerations, Mar. Geol., 352, 111-154, https://doi.org/10.1016/j.margeo.2014.03.011, 2014.

Reinardy, B. T. I., Escutia, C., Iwai, M., Jimenez-Espejo, F. J., Cook, C., van de Flierdt, T., and Brinkhuis, H.: Repeated advance and retreat of the East Antarctic Ice Sheet on the continental shelf during the early Pliocene warm period, Palaeogeogr. Palaeocl., 422, 65-84, https://doi.org/10.1016/j.palaeo.2015.01.009, 2015.

Richter, T. O., van der Gaast, S., Koster, B., Vaars, A., Gieles, R., de Stigter, H. C., De Haas, H., and van Weering, T. C. E.: The Avaatech XRF Core Scanner: technical description and applications to NE Atlantic sediments, Geol. Soc. Spec. Publ., 267, 3950, https://doi.org/10.1144/GSL.SP.2006.267.01.03, 2006.

Rignot, E., Jacobs, S., Mouginot, J., and Scheuchl, B.: Iceshelf melting around Antarctica, Science, 341, 266-70, https://doi.org/10.1126/science.1235798, 2013.

Rodriguez, A. B. and Anderson, J. B.: Contourite origin for shelf and upper slope sand sheet, offshore Antarctica, Sedimentology, 51, 699-711, https://doi.org/10.1111/j.1365-3091.2004.00645.x, 2004.

Roeske, T.: Dissolved Barium and Particulate Rare Earth Elements as Tracers for Shelf-Basin Interaction in the Arctic Ocean, PhD Thesis, Universität Bremen, available at: http://epic.awi.de/ 26084/ (last access: July 2018, 2011.

Rothwell, R. G. and Croudace, I. W.: Micro-XRF Studies of Sediment Cores, edited by: Croudace, I. W. and Rothwell, R. G., Springer Netherlands, Dordrecht, 2015.

Salabarnada, A., Escutia, C., Röhl, U., Nelson, C. H., McKay, R. M., Jiménez-Espejo, F. J., Bijl, P. K., Hartman, J. D., Ikehara, M., Strother, S. L., Salzmann, U., Evangelinos, D., LópezQuirós, A., Flores, J. A., Sangiorgi, F., and Brinkhuis, H.: Late Oligocene XRF scanner data from IODP Site 318-U1356 Willkes Land Margin, Antarctica, PANGAEA, available at: https://doi. pangaea.de/10.1594/PANGAEA.892208 (last access: July 2018.

Salzmann, U., Strother, S., Sangiorgi, F., Bijl, P., Pross, J., Woodward, J., Escutia, C., and Brinkhuis, H.: Oligocene to Miocene terrestrial climate change and the demise of forests on Wilkes Land, East Antarctica, in: EGU General Assembly Conference Abstracts, 18, EPSC2016-2717, 2016.

Sangiorgi, F., Bijl, P. K., Passchier, S., Salzmann, U., Schouten, S., McKay, R., Cody, R. D., Pross, J., van de Flierdt, T., Bohaty, S. M., Levy, R., Williams, T., Escutia, C., and Brinkhuis, H.: Southern Ocean warming and Wilkes Land ice sheet retreat during the mid-Miocene, Nat. Commun., 9, 317, https://doi.org/10.1038/s41467-017-02609-7, 2018.

Scher, H. D. and Martin, E. E.: Oligocene deep water export from the North Atlantic and the development of the Antarctic Circumpolar Current examined with neodymium isotopes, Paleoceanography, 23, https://doi.org/10.1029/2006PA001400, 2008.

Scher, H. D., Whittaker, J. M., Williams, S. E., Latimer, J. C., Kordesch, W. E. C., and Delaney, M. L.: Onset of Antarctic Circumpolar Current 30 million years ago as Tasmanian Gateway aligned with westerlies, Nature, 523, 580-583, https://doi.org/10.1038/nature14598, 2015.

Schneider, R. R., Price, B., Müller, P. J., Kroon, D., and Alexander, I.: Monsoon related variations in Zaire (Congo) sediment load and influence of fluvial silicate supply on marine productivity in the east equatorial Atlantic during the last 200,000 years, Paleoceanography, 12, 463-481, https://doi.org/10.1029/96PA03640, 1997.

Shanmugam, G.: Deep-water Bottom Currents and their Deposits, in Developments in Sedimentology, chap. 5, 60, 59-81, 2008.

Shanmugam, G., Spalding, T. D., and Rofheart, D. H.: Traction structures in deep-marine, bottom-current-reworked sands in the Pliocene and Pleistocene, Gulf of Mexico, Geology, 21, 929-932, https://doi.org/10.1130/00917613(1993)021<0929:TSIDMB>2.3.CO;2, 1993.

Shen, Q., Wang, H., Shum, C. K., Jiang, L., Hsu, H. T., and Dong, J.: Recent high-resolution Antarctic ice velocity maps reveal increased mass loss in Wilkes Land, East Antarctica, Sci. Rep., 8, 4477, https://doi.org/10.1038/s41598-018-22765-0, 2018.

Solomon, S., Qin, D., Manning, M., Chen, Z., Marquis, M., Averyt, K., Tignor, M. B., and Miller, H. L., (Eds.): IPCC, 2007: Climate Change 2007: The Physical Science Basis. Contribution of Working Group I to the Fourth Assessment Report of the Intergovernmental Panel on Climate Change, Cambridge University Press, Cambridge, United Kingdom and New York, NY, USA, 2007.

St-Onge, G. and Long, B. F.: CAT-scan analysis of sedimentary sequences: An ultrahigh-resolution paleoclimatic tool, Eng. Geol., 103, 127-133, https://doi.org/10.1016/j.enggeo.2008.06.016, 2009.

Stow, D.: Deep-water contourite systems: modern drifts and ancient series, seismic and sedimentary characteristics, Geol. Soc., London, 2002.

Stow, D. and Faugères, J.-C.: Contourite Facies and the Facies Model, chap. 13, 223-256, 2008.

Strother, S. L., Salzmann, U., Sangiorgi, F., Bijl, P. K., Pross, J., Escutia, C., Salabarnada, A., Pound, M. J., Voss, J., and Woodward, J.: A new quantitative approach to identify reworking in Eocene to Miocene pollen records from offshore Antarctica using red fluorescence and digital imaging, Biogeosciences, 14, 2089-2100, https://doi.org/10.5194/bg-14-2089-2017, 2017.

Tauxe, L., Stickley, C. E., Sugisaki, S., Bijl, P. K., Bohaty, S. M., Brinkhuis, H., Escutia, C., Flores, J. a., Houben, a. J. P., Iwai, M., Jiménez-Espejo, F., McKay, R., Passchier, S., Pross, J., Riesselman, C. R., Röhl, U., Sangiorgi, F., Welsh, K., Klaus, A., Fehr, A., Bendle, J. a. P., Dunbar, R., Gonzàlez, J., Hayden, T., Katsuki, K., Olney, M. P., Pekar, S. F., Shrivastava, P. K., van de Flierdt, T., Williams, T. and Yamane, M.: Chronostratigraphic framework for the IODP Expedition 318 cores from the Wilkes Land 
Margin: Constraints for paleoceanographic reconstruction, Paleoceanography, 27, https://doi.org/10.1029/2012PA002308, 2012.

Thorn, V.: Oligocene and early Miocene phytolits from CRP-2/2A and CRP-3, Victoria Land Basin, Antarctica, Terra Antart., 8, 407-422, 2001.

Tjallingii, R., Röhl, U., Kölling, M., and Bickert, T.: Influence of the water content on X-ray fluorescence core-scanning measurements in soft marine sediments, Geochem. Geophy. Geosy., 8, https://doi.org/10.1029/2006GC001393, 2007.

Toggweiler, J. R. and Russell, J.: Ocean circulation in a warming climate, Nature, 451, 286-288, https://doi.org/10.1038/nature06590, 2008.

Tribovillard, N., Algeo, T. J., Lyons, T., and Riboulleau, A.: Trace metals as paleoredox and paleoproductivity proxies: An update, Chem. Geol., 232, 12-32, https://doi.org/10.1016/j.chemgeo.2006.02.012, 2006.

Van Daele, M., Cnudde, V., Duyck, P., Pino, M., Urrutia, R., and De Batist, M.: Multidirectional, synchronously-triggered seismoturbidites and debrites revealed by X-ray computed tomography (CT), edited by: Trofimovs, J., Sedimentology, 61, 861-880, https://doi.org/10.1111/sed.12070, 2014.

Vandenberghe, N., Hilgen, F. J., Speijer, R. P., Ogg, J. G., Gradstein, F. M., Hammer, O., Hollis, C. J., and Hooker, J. J.: The Paleogene Period, in: The Geologic Time Scale, Elsevier, 855-921, 2012.

van Hinsbergen, D. J. J., de Groot, L. V., van Schaik, S. J., Spakman, W., Bijl, P. K., Sluijs, A., Langereis, C. G., and Brinkhuis, H.: A Paleolatitude Calculator for Paleoclimate Studies, edited by: Royer, D. L., PLoS One, 10, e0126946, https://doi.org/10.1371/journal.pone.0126946, 2015.

van Wijk, E. M. and Rintoul, S. R.: Freshening drives contraction of Antarctic Bottom Water in the Australian Antarctic Basin, Geophys. Res. Lett., 41, 1657-1664, https://doi.org/10.1002/2013GL058921, 2014.

Veldkamp, A. and Kroonenberg, S. B.: Application of bulk sand geochemistry in mineral exploration and Quaternary research: a methodological study of the Allier and Dore terrace sands, Limagne rift valley, France, Appl. Geochem., 8, 177-187, https://doi.org/10.1016/0883-2927(93)90033-D, 1993.

Villa, G. and Persico, D.: Late Oligocene climatic changes: Evidence from calcareous nannofossils at Kerguelen Plateau Site 748 (Southern Ocean), Palaeogeogr. Palaeocl., 231, 110-119, https://doi.org/10.1016/j.palaeo.2005.07.028, 2006.

Villa, G., Persico, D., Wise, S. W., and Gadaleta, A.: Calcareous nannofossil evidence for Marine Isotope Stage 31 (1 Ma) in Core AND-1B, ANDRILL McMurdo Ice Shelf Project (Antarctica), Glob. Planet. Change, 96-97, 75-86, https://doi.org/10.1016/j.gloplacha.2009.12.003, 2012.

Wanlu, F., Jiang, D., Montañez, I. P., Meyers, S. R., Motani, R., and Tintori, A.: Eccentricity and obliquity paced carbon cycling in the Early Triassic and implications for post-extinction ecosystem recovery, Sci. Rep., 6, 27793, https://doi.org/10.1038/srep27793, 2016.
Weertman, J.: Stability of the Junction of an Ice Sheet and an Ice Shelf, J. Glaciol., 13, 3-11, https://doi.org/10.3189/S0022143000023327, 1974.

Whitehead, J. M. and Bohaty, S. M.: Pliocene summer sea surface temperature reconstruction using silicoflagellates from Southern Ocean ODP Site 1165, Paleoceanography, 18, https://doi.org/10.1029/2002PA000829, 2003.

Whitehead, J. M., Wotherspoon, S., and Bohaty, S. M.: Minimal Antarctic sea ice during the Pliocene, Geology, 33, 137, https://doi.org/10.1130/G21013.1, 2005.

Wilhelms-Dick, D., Westerhold, T., Röhl, U., Wilhelms, F., Vogt, C., Hanebuth, T. J. J., Römmermann, H., Kriews, M., and Kasten, S.: A comparison of $\mathrm{mm}$ scale resolution techniques for element analysis in sediment cores, J. Anal. At. Spectrom., 27, 1574, https://doi.org/10.1039/c2ja30148b, 2012.

Williams, T. and Handwerger, D.: A high-resolution record of early Miocene Antarctic glacial history from ODP Site 1165, Prydz Bay, Paleoceanography, 20, https://doi.org/10.1029/2004PA001067, 2005.

Wilson, G. S., Levy, R. H., Naish, T. R., Powell, R. D., Florindo, F., Ohneiser, C., Sagnotti, L., Winter, D.M., Cody, R., Henrys, S., Ross, J., Krissek, L., Niessen, F., Pompillio, M., Scherer, R., Alloway, B. V., Barrett, P. J., Brachfeld, S., Browne, G., Carter, L., Cowan, E., Crampton, J., DeConto, R. M., Dunbar, G., Dunbar, N., Dunbar, R., von Eynatten, H., Gebhardt, C., Giorgetti, G., Graham, I., Hannah, M., Hansaraj, D., Harwood, D. M., Hinnov, L., Jarrard, R. D., Joseph, L., Kominz, M., Kuhn, G., Kyle, P., Läufer, A., McIntosh, W. C., McKay, R., Maffioli, P., Magens, D., Millan, C., Monien, D., Morin, R., Paulsen, T., Persico, D., Pollard, D., Raine, J.I., Riesselman, C., Sandroni, S., Schmitt, D., Sjunneskog, C., Strong, C. P., Talarico, F., Taviani, M., Villa, G., Vogel, S., Wilch, T., Williams, T., Wilson, T. J., and Wise, S.: Neogene tectonic and climatic evolution of the Western Ross Sea, Antarctica - Chronology of events from the AND-1B drill hole, Glob. Planet. Change, 96-97, 189-203, https://doi.org/10.1016/j.gloplacha.2012.05.019, 2012.

Zachos, J.: Trends, Rhythms, and Aberrations in Global Climate 65 Ma to Present, Science, 292, 686-693, 85, https://doi.org/10.1126/science.1059412, 2001.

Zachos, J., Kroon, D., Bloom, P., and Et, A.: Initial Reports Leg 208, Proc. Ocean Drill. Progr., 208, 1-112, 2004.

Zhang, Y. G., Pagani, M., Liu, Z., Bohaty, S. M., and DeConto, R.: A 40-million-year history of atmospheric $\mathrm{CO}_{2}$, Philos. T. Roy. Soc. A., 371, 20130096-20130096, https://doi.org/10.1098/rsta.2013.0096, 2013.

Ziegler, M., Jilbert, T., de Lange, G.J., Lourens, L. J., and Reichart, G.-J.: Bromine counts from XRF scanning as an estimate of the marine organic carbon content of sediment cores, Geochem. Geophy. Geosy., 9, https://doi.org/10.1029/2007GC001932, 2008. 